\title{
Monogenean parasites of sardines in Lake Tanganyika: diversity, origin and intra- specific variability
}

Nikol Kmentová ${ }^{1,15}$, Maarten Van Steenberge ${ }^{2,3,4,5}$, Joost A.M. Raeymaekers ${ }^{5,6,7}$, Stephan Koblmüller ${ }^{4}$, Pascal I. Hablützel ${ }^{5,8}$, Fidel Muterezi Bukinga ${ }^{9}$, Théophile Mulimbwa N'sibula9 ${ }^{9}$ Pascal Masilya Mulungula ${ }^{9}$, Benoît Nzigidahera $\dagger^{10}$, Gaspard Ntakimazi ${ }^{11}$, Milan Gelnar ${ }^{1}$, Maarten P.M. Vanhove ${ }^{1,5,12,13,14}$

${ }^{1}$ Department of Botany and Zoology, Faculty of Science, Masaryk University, Kotlářská 2, 61137 Brno, Czech Republic

2 Biology Department, Royal Museum for Central Africa, Leuvensesteenweg 13, 3080, Tervuren, Belgium

${ }^{3}$ Operational Directorate Taxonomy and Phylogeny, Royal Belgian Institute of Natural Sciences, Vautierstraat 29, B-1000 Brussels, Belgium

${ }^{4}$ Institute of Biology, University of Graz, Universitätsplatz 2, A-8010 Graz, Austria

${ }^{5}$ Laboratory of Biodiversity and Evolutionary Genomics, Department of Biology, University of Leuven, Ch. Deberiotstraat 32, B-3000 Leuven, Belgium

${ }^{6}$ Centre for Biodiversity Dynamics, Department of Biology, Norwegian University of Science and Technology, N-7491 Trondheim, Norway

${ }^{7}$ Faculty of Biosciences and Aquaculture, Nord University, N-8049 Bod $\phi$, Norway

${ }^{8}$ Flanders Marine Institute, Wandelaarkaai 7, 8400 Oostende, Belgium

${ }^{9}$ Centre de Recherche en Hydrobiologie, Département de Biologie, B.P. 73 Uvira, Democratic Republic of Congo

${ }^{10}$ Office Burundais pour la Protection de l'Environnement, Centre de Recherche en Biodiversité, Avenue de l'Imprimerie Jabe 12, B.P. 2757, Bujumbura, Burundi

${ }^{11}$ Département de Biologie, Université du Burundi, Campus Mutanga, B.P. 2700, Bujumbura, Burundi

${ }^{12}$ Capacities for Biodiversity and Sustainable Development, Operational Directorate Natural Environment, Royal Belgian Institute of Natural Sciences, Vautierstraat 29, B-1000 Brussels, Belgium

${ }^{13}$ Centre for Environmental Sciences, Research Group Zoology: Biodiversity and Toxicology, Hasselt University, Agoralaan Gebouw D, B-3590 Diepenbeek, Belgium

${ }^{14}$ Zoology Unit, Finnish Museum of Natural History, University of Helsinki, P.O.Box 17, Helsinki FI-00014, Finland

${ }^{15}$ E-mail:kmentovan@mail.muni.cz

Keywords: Clupeidae, Dactylogyridae, fisheries targets, phenotypic variability, phylogeny

\begin{abstract}
Whereas Lake Tanganyika's littoral and benthic zones are famous for their diverse fish communities, its pelagic zone is dominated by few species, of which two representatives of Clupeidae (Limnothrissa miodon and Stolothrissa tanganicae) take a pivotal role. We investigated the monogenean fauna infecting these freshwater clupeids to explore the link between parasite morphology and host species identity, or seasonal and geographical origin, which may reveal host population structure. Furthermore, we conducted phylogenetic analyses to test whether these parasitic flatworms mirror their host species' marine origin. Based on 406 parasite specimens infecting 385 host specimens, two monogenean species of Kapentagyrus Kmentová, Gelnar and Vanhove, gen. nov. were morphologically identified and placed in the phylogeny of Dactylogyridae using three molecular markers. One of the species, Kapentagyrus limnotrissae comb. nov., is host-specific to L. miodon while its congener, which is new to science and described as Kapentagyrus tanganicanus Kmentová, Gelnar and Vanhove, sp. nov., is infecting both
\end{abstract}

clupeid species. Morphometrics of the parasites' hard parts showed intra-specific variability, related to host species identity and seasonality in K. tanganicanus. Significant intra-specific differences in haptor morphometrics between the northern and southern end of Lake Tanganyika were found, and support the potential use of monogeneans as tags for host population structure. Based on phylogenetic inference, we suggest a freshwater origin of the currently known monogenean species infecting clupeids in Africa, with the two species from Lake Tanganyika representing a quite distinct lineage.

\section{Contents}

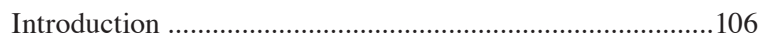

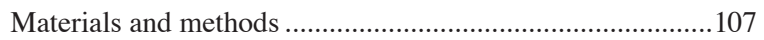

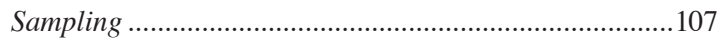

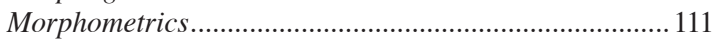

Molecular characterisation ............................................... 112 


\begin{tabular}{|c|c|}
\hline Results ........................ & .114 \\
\hline Monogenean specic &. .114 \\
\hline Morphometrics...... &. .114 \\
\hline Discussion ....................... &. .117 \\
\hline Intra-specific morp &. .119 \\
\hline Monogenean host-s &. .120 \\
\hline $\begin{array}{l}\text { Phylogenetic positi } \\
\text { in Lake Tanganyiko }\end{array}$ & \\
\hline Conclusions ................... &. .121 \\
\hline 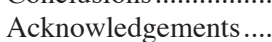 &. .122 \\
\hline 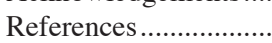 & .122 \\
\hline 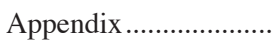 & \\
\hline
\end{tabular}

\section{Introduction}

Lake Tanganyika is a unique freshwater ecosystem that is famous for its remarkable species richness and high levels of endemism (Moore, 1897; Coulter, 1991a). The lake was formed by tectonic rifting in East Africa between 9 and 12 million years ago (MYA) (Cohen et al., 1993).In the past, geological processes and recurrent cycles of droughts and increased humidity caused lake level fluctuations with an extent of several hundreds of meters, potentially leading to recurrent separation of the lake's three sub-basins (Danley et al., 2012). It is suggested that those processes played an important role in shaping the lake's biodiversity (Sturmbauer et al., 2001; Sefc et al., 2017) and productivity (Cohen et al., 2006). Lake Tanganyika has attracted scientific interest for decades, mainly because of its diverse cichlid species assemblage, which comprises over 200 endemic species (Koblmüller et al., 2008). Together with the endemic cichlid radiations of Lake Malawi and the region of Lake Victoria, it forms one of the prime model systems for studying adaptive radiation and speciation in vertebrates (e.g. Turner, 2007; Santos and Salzburger, 2012; Muschick et al., 2014). However, besides cichlids, numerous other fish and invertebrate taxa also radiated into flocks of largely endemic species in Lake Tanganyika (e.g. Fryer, 1991; Michel, 1995; Koblmüller et al., 2006; Marijnissen et al., 2006; Day and Wilkinson, 2006; Meixner et al., 2007; Glaubrecht, 2008; Brown et al., 2010; Erpenbeck et al., 2011; Peart et al., 2014; Vanhove et al., 2015). This makes Lake Tanganyika an ideal study system for studying patterns of intra-lacustrine radiation across a variety of taxa.

Contrary to the lake's littoral, the pelagic zone is relatively poor in terms of fish species richness. It is dominated by two endemic clupeids, Limnothrissa miodon (Boulenger, 1906) and Stolothrissa tanganicae Regan, 1917 and four endemic latid predators, Lates angustifrons Boulenger, 1906, L. mariae Steindachner, 1909, L. microlepis Boulenger, 1898, and L. stappersii (Boulenger, 1914) (Hecky, 1991). Worldwide, Clupeidae comprises 197 species (Nelson, 2006; Eschmeyer and Fong, 2017), of which 27 strictly riverine species of Dorosomatinae are found in Africa (Lavoué et al., 2014). Originating from a marine environment, clupeids have expanded across Africa starting from the north-western coast (Wilson et al., 2008). The ancestors of the two present-day Lake Tanganyika endemics, L. miodon and S. tanganicae reached the area of the Congo Basin around 27 MYA and diverged 8 MYA in the emerging Lake Tanganyika (Wilson et al., 2008). Both species have a lake-wide distribution, a short lifespan, a nocturnal vertical migration to feed on plankton, and schooling behaviour. Two nominal species have been recognised previously in Limnothrissa: L. miodon and L. stappersii (Poll, 1948). However, we consider L. stappersii a synonym of L. miodon, in view of the detailed study performed by Gourène and Teugels (1993), which demonstrated that the differences between the two nominal species could be interpreted as juvenile traits, and in view of the fact that no motivation was given for the revalidation of L. stappersii by Poll and Gosse (1995). Hence, Limnothrissa and Stolothrissa are monotypic genera.

Clupeids are an important part of the food web as they link the planktonic and piscivorous trophic levels (Hecky et al., 1981). Fluctuations of clupeid populations in Lake Tanganyika on an annual and a seasonal basis (dry and wet season) are related to environmental changes (Coulter, 1976; Hecky, 1991; Marshall, 1993; Plisnier et al., 2009). Stolothrissa tanganicae is the most abundant fish species in the lake and is the principal food source for large-sized pelagic fish. Juveniles of $L$. miodon feed on plankton and their adults also prey on juvenile representatives of Limnothrissa and on adult and juvenile specimens of Stolothrissa that mostly inhabit the pelagic zone. Reproducing populations and juveniles of L. miodon are found in bays, inshore waters and river deltas (Coulter, 1970; Marshall, 1993; Mulimbwa and Shirakihara, 1994). In contrast to L. miodon, S. tanganicae tends to stay more offshore from its early life stages onwards, with adults feeding only on plankton (Chapman and van Well, 1978; Plisnier et al., 2009). While significant geographical morphological variability was found in L. miodon, there is thus far no evidence for significant population genetic structure on neither small nor large geographical scales (Hauser et al., 1995, 1998). Interestingly, previous studies in other systems already 
demonstrated the potential use of parasites as tags for fish population structure on the level of parasite community composition (Oliva and Gonzalez, 2004; Criscione et al., 2006; Poulin and Kamiya, 2015).

Although clupeids are important components of the food web and form the main fisheries in Lake Tanganyika, almost nothing is known about their parasite fauna. Only one helminth species has been described: the monogenean flatworm Ancyrocephalus limnotrissae Paperna, 1973, which infects the gills of L. miodon (Paperna, 1973). Monogenea is a class of parasitic flatworms (Platyhelminthes) characterised by a one-host life cycle with fish as their main hosts, a worldwide distribution and usually a high level of host-specificity (Pugachev et al., 2009). Despite their important role in all levels of ecosystem productivity (Kuris et al., 2008; Preston et al., 2013), parasites have been almost ignored in Lake Tanganyika for many decades. Systematic studies on the lake's parasite fauna are still fragmentary and only a tiny fraction of potential hosts has been investigated. Hitherto, such surveys have led to species descriptions of parasites from 25 host fish species, 19 of which were cichlids (Coulter, 1991b; Kmentová et al., 2016). Nevertheless, over the last decade, an increasing number of surveys has been conducted, including studies on ecological and evolutionary mechanisms behind parasite diversity and on the potential interplay with host evolution (Raeymaekers et al., 2013; Hablützel et al., 2014, 2016, 2017; Grégoir et al., 2015). Most recent taxonomic studies focused on monogeneans infecting cichlids in the species-rich littoral zone (see overview in Kmentová et al., 2016). Interestingly, while a high host-specificity was observed in monogeneans infecting cichlids in Lake Tanganyika's littoral zone (Vanhove et al., 2015), the observed lower level of host-specificity reported on bathypelagic cichlids of the tribe Bathybatini (Pariselle et al., 2015; Kmentová et al.,2016) resembles the situation in pelagic and deep water marine environments (Dogiel and Bogolepova, 1957; Rohde, 1980; Justine et al., 2012; Schoelinck et al., 2012). This phenomenon has been explained by lower host species densities and increased home range compared to the littoral habitat and hence a decreasing speciation rate of parasites (Rohde, 1988).

Lake Tanganyika consists of three different subbasins. Although the lake never desiccated, it is very likely that these sub-basins were at times separated due to fluctuations in water level (Danley et al., 2012). Moreover, latitudinal differences in mixing due to prevailing winds (Langenberg et al., 2002) resulted in different depths of the oxygenated layer (Coenen et al., 1993). These factors have contributed to limnological differences among sub-basins with consequences for fish communities and hence, potentially, also their parasites. The effect of geographic variation (Kmentová et al., 2016), seasonality (Mo, 1991; Dávidová et al., 2005) and host species (Šimková et al., 2001a; Kmentová et al., 2016) on parasite morphology at the intra-specific level has been extensively documented.

As mentioned above, almost nothing is known about the geographical population structure of the two clupeid species from Lake Tanganyika, even though they are of great economic importance. As monogeneans are parasites with a direct life cycle and low pathogenicity, they have already been used as markers for host population structure in other fish (MacKenzie, 1983; Williams et al., 1992). Clupeidae have a primary marine origin and the majority of its representatives in oceans worldwide are known to be infected by monogenean species, mainly from Mazocraeidae (Gérard et al., 2015), but also from Microcotylidae (Mendoza-Garfias and Pérez-Ponce de Léon, 1998) and Gyrodactylidae (Huyse and Malmberg, 2004). The origin of the monogeneans infecting African freshwater clupeids, which were described as representatives of Dactylogyridae, has never been investigated.

Here, we provide the first comprehensive study on the monogenean parasite diversity of the two economically important clupeids from Lake Tanganyika to answer four questions. (1) Which monogenean parasites infect clupeids in Lake Tanganyika? (2) Do monogeneans on these clupeids follow the pattern of low host-specificity that was already observed in other parasites from the lake's pelagic zone? (3) Is the morphology of monogeneans affected by seasonality, host species identity or geographic origin, and can monogenean parasites, therefore, be used for host stock identification? (4) Can the origin of these monogeneans be inferred from phylogenetic data?

\section{Materials and methods}

\section{Sampling}

Specimens of the two species of clupeids (Limnothrissa miodon, Stolothrissa tanganicae) were sampled from 19 localities in Lake Tanganyika (see Table 1, Fig. 1). Samples included specimens from the ichthyology 

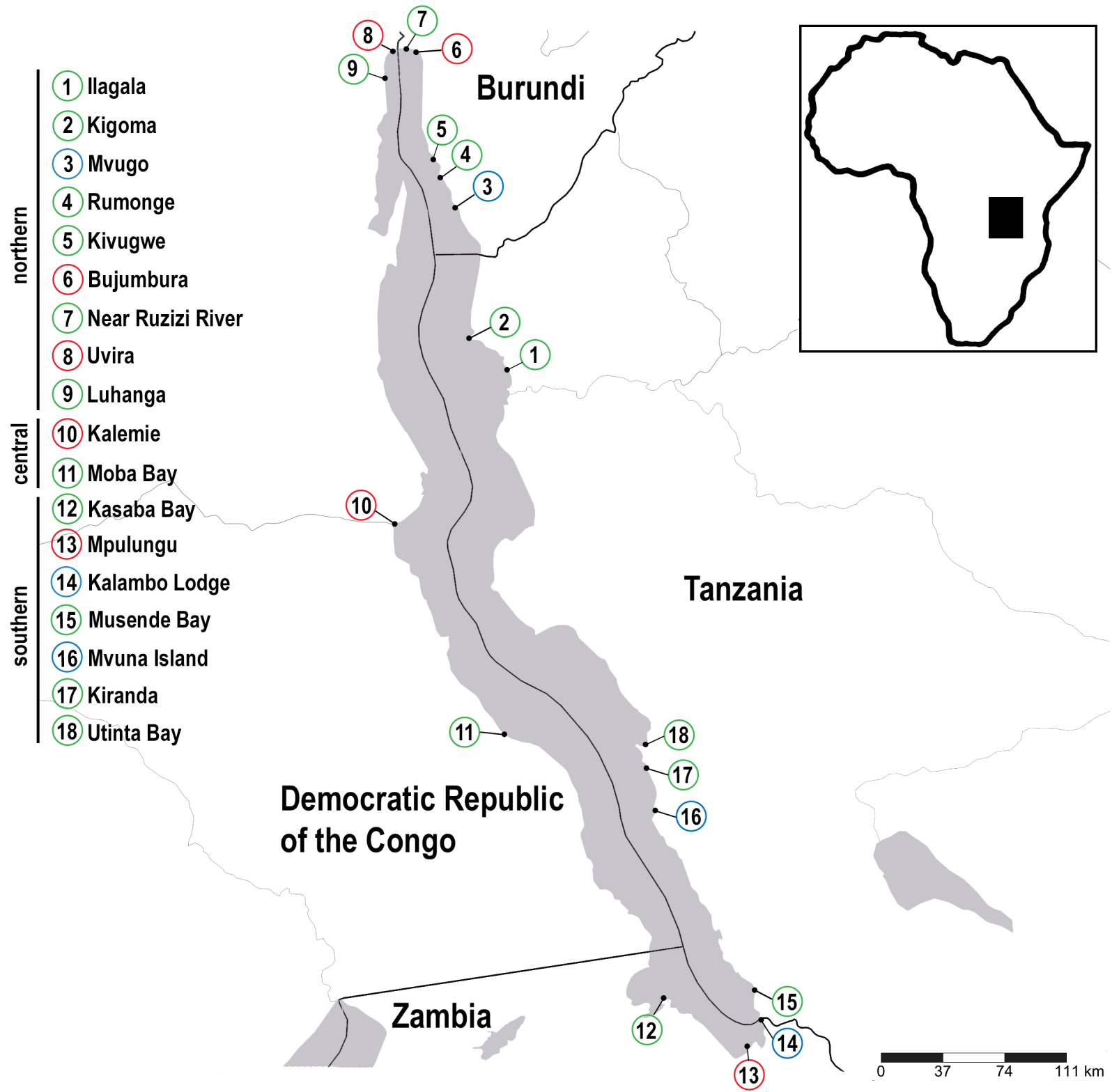

\section{Recent sampling + RMCA $\bigcirc$ RMCA $\bigcirc$ Recent sampling}

Figure 1. Sampling localities in Lake Tanganyika including sub-basin specification. Map created using SimpleMappr software v7.0.0. (available at http://www.simplemappr.net. Accessed April 20, 2017).

collection of the Royal Museum for Central Africa (RMCA) (Tervuren, Belgium) and fresh specimens that were either obtained from local fishermen or caught with gill nets from the experimental fishing unit of the Centre de Recherche en Hydrobiologie Uvira (CRH) (Uvira, Democratic Republic of the Congo, August 2016) (see Fig. 1). In total, gills and fins of 385 fish specimens were examined following the standard protocol of Ergens and Lom (1970). Infection parameters such as prevalence (percentage of infected hosts) and infection intensity (mean number of monogenean individuals per infected host) were calculated following Ergens and Lom (1970). Monogeneans were mounted on slides using a solution of glycerine ammonium picrate (GAP) or, in the case of specimens retrieved from hosts from 
Table 1. An overview of host species examined for monogenean parasites with localities and infection parameters (Kapentagyrus limnotrissae before and $K$. tanganicanus behind slashes).

\begin{tabular}{|c|c|c|c|c|c|c|c|}
\hline Host species & $\begin{array}{l}\text { Locality (geographic } \\
\text { coordinates, year) }\end{array}$ & $\begin{array}{l}\text { Locality - basins } \\
\text { (Danley et al., } \\
\text { 2012) }\end{array}$ & $\begin{array}{l}\text { Number of } \\
\text { fish specimens } \\
\text { (accession number } \\
\text { in RMCA) }\end{array}$ & $\begin{array}{l}\text { Number of } \\
\text { monogenean } \\
\text { individuals }\end{array}$ & $\begin{array}{l}\text { Prevalence } \\
(\%)\end{array}$ & $\begin{array}{l}\text { Infection } \\
\text { intensity/one } \\
\text { gill chamber }\end{array}$ & $\begin{array}{l}\text { Abundance/one } \\
\text { gill chamber } \\
\text { (range) }\end{array}$ \\
\hline \multirow[t]{16}{*}{$\begin{array}{l}\text { Limnothrissa } \\
\text { miodon }\end{array}$} & $\begin{array}{l}\text { Bujumbura } \\
\left(3^{\circ} 23^{\prime} \mathrm{S}-29^{\circ} 22^{\prime} \mathrm{E} \text {, }\right. \\
1.7 .-31.7 .1928)\end{array}$ & The northern basin & $\begin{array}{l}2 \text { (MRAC 23567- } \\
68)\end{array}$ & $0 / 0$ & $0 / 0$ & $0 / 0$ & $0 / 0$ \\
\hline & $\begin{array}{l}\text { Bujumbura (1.2.- } \\
28.2 .1935)\end{array}$ & The northern basin & $\begin{array}{l}11 \text { (MRAC 43554- } \\
64)\end{array}$ & $1 / 0$ & $9 / 0$ & $1 / 0$ & $0.09(0-1) / 0$ \\
\hline & $\begin{array}{l}\text { Kalemie } \\
\left(5^{\circ} 56^{\prime} \mathrm{S}-29^{\circ} 12^{\prime} \mathrm{E},\right. \\
22.10 .1946)\end{array}$ & The central basin & $\begin{array}{l}8 \text { (MRAC 88891- } \\
89098)\end{array}$ & $4 / 0$ & $25 / 0$ & $2 / 0$ & $0.5(0-3) / 0$ \\
\hline & $\begin{array}{l}\text { Kalemie (1.1.- } \\
31.1 .1946)\end{array}$ & The central basin & 1 (MRAC 89151) & $2 / 0$ & $100 / 0$ & $2 / 0$ & $2 / 0$ \\
\hline & $\begin{array}{l}\text { Kalemie } \\
(20.11 .1946)\end{array}$ & The central basin & $\begin{array}{l}8 \text { (MRAC } 89137- \\
144)\end{array}$ & $22 / 0$ & $25 / 0$ & $5.5 / 0$ & $2.75(0-9) / 0$ \\
\hline & Kalemie (11.8.2016) & The central basin & $10(-)$ & $55 / 5$ & $80 / 33$ & $6.9 / 1.7$ & $\begin{array}{l}5.5(0-15) / 0.5(0- \\
2)\end{array}$ \\
\hline & $\begin{array}{l}\text { Kasaba Bay } \\
\left(8^{\circ} 31^{\prime} \mathrm{S}-30^{\circ} 42^{\prime} \mathrm{E},\right. \\
1.1 .1967)\end{array}$ & The southern basin & $\begin{array}{l}2 \text { (MRAC 190150- } \\
151)\end{array}$ & $0 / 49$ & $0 / 100$ & $0 / 29.5$ & $0 / 29.5(12-37)$ \\
\hline & $\begin{array}{l}\text { Kigoma Bay } \\
\left(4^{\circ} 88^{\prime} \mathrm{S}-29^{\circ} 61^{\prime} \mathrm{E} \text {, }\right. \\
\text { 12.4.-13.4.1947) }\end{array}$ & The northern basin & $\begin{array}{l}4 \text { (MRAC 89367- } \\
70)\end{array}$ & $2 / 0$ & $25 / 0$ & $2 / 0$ & $0.5(0-4) / 0$ \\
\hline & $\begin{array}{l}\text { Kiranda } \\
\left(07^{\circ} 25^{\prime} \mathrm{S}-30^{\circ} 36^{\prime} \mathrm{E},\right. \\
11.3 .1947)\end{array}$ & The southern basin & $\begin{array}{l}2 \text { (MRAC 89311- } \\
12)\end{array}$ & $9 / 0$ & $50 / 0$ & $9 / 0$ & $4.5(0-9) / 0$ \\
\hline & $\begin{array}{l}\text { Kivugwe } \\
\left(3^{\circ} 80^{\prime} \mathrm{S}-29^{\circ} 34^{\prime} \mathrm{E},\right. \\
22.2 .1994)\end{array}$ & The northern basin & $\begin{array}{l}7 \text { (MRAC } \\
94069.0369-70)\end{array}$ & $2 / 0$ & $28.6 / 0$ & $1 / 0$ & $0.28(0-1) / 0$ \\
\hline & $\begin{array}{l}\text { Kasaba Bay } \\
(5.3 .1947)\end{array}$ & The southern basin & 1 (MRAC 89353) & $1 / 2$ & $100 / 100$ & $1 / 2$ & $1 / 2$ \\
\hline & $\begin{array}{l}\text { Luhanga } \\
\left(3^{\circ} 52^{\prime} \mathrm{S}-29^{\circ} 15^{\prime} \mathrm{E} \text {, }\right. \\
26.4 .1994)\end{array}$ & The northern basin & $\begin{array}{l}2 \text { (MRAC } \\
94069.2375-76)\end{array}$ & $0 / 1$ & $0 / 50$ & $0 / 1$ & $0 / 0.5(0-1)$ \\
\hline & $\begin{array}{l}\text { Moba Bay } \\
\left(7^{\circ} 03^{\prime} \mathrm{S}-29^{\circ} 47^{\prime} \mathrm{E},\right. \\
21.3 .1947)\end{array}$ & The central basin & $\begin{array}{l}2 \text { (MRAC 89335- } \\
36)\end{array}$ & $9 / 0$ & $50 / 0$ & $11 / 0$ & $5.5(0-11) / 0$ \\
\hline & $\begin{array}{l}\text { Mpulungu } \\
\left(8^{\circ} 46^{\prime} \mathrm{S}-31^{\circ} 07^{\prime} \mathrm{E},\right. \\
14.3 .1966)\end{array}$ & The southern basin & $\begin{array}{l}3 \text { (MRAC } 189612- \\
14)\end{array}$ & $1 / 0$ & $33.3 / 0$ & $1 / 0$ & $0.33(0-1) / 0$ \\
\hline & $\begin{array}{l}\text { Mpulungu } \\
(19.8 .2016)\end{array}$ & The southern basin & $2(-)$ & $4 / 0$ & $50 / 0$ & $4 / 0$ & $2(0-4) / 0$ \\
\hline & $\begin{array}{l}\text { Mvugo } \\
\left(4^{\circ} 18^{\prime} S-29^{\circ} 34^{\prime} \mathrm{E},\right. \\
4.8 .2016)\end{array}$ & The northern basin & $6(-)$ & $9 / 25$ & $50 / 100$ & $3 / 4.2$ & $1.5 / 4.2(1-10)$ \\
\hline
\end{tabular}


$\begin{array}{ll}\text { Host species } & \begin{array}{l}\text { Locality (geographic } \\ \text { coordinates, year) }\end{array} \\ \text { (Danley et al., } & \text { 2012) }\end{array}$
Number of

fish specimens

(accession number

in RMCA)

$\begin{array}{llll}\begin{array}{l}\text { Number of } \\ \text { monogenean } \\ \text { individuals }\end{array} & \begin{array}{l}\text { Prevalence } \\ (\%)\end{array} & \begin{array}{l}\text { Infection } \\ \text { intensity/one } \\ \text { gill chamber }\end{array} & \begin{array}{l}\text { Abundance/one } \\ \text { (range) }\end{array}\end{array}$

Mvuna Island

( $7^{\circ} 26^{\prime} \mathrm{S} 30^{\circ} 32^{\prime} \mathrm{E}, \quad$ The southern basin $6(-)$

18.8.2015)

Near Ruzizi

(250'S-2902'E, The northern basin 2 (MRAC 99633 -

2.12.1954)

34) $6 / 0$

$11 / 5$

$50 / 50$

$3.7 / 1.7$

$1.8(0-8) / 0.83(0-$ 3

Near Ruzizi

(26.10.1954)

$\begin{array}{ll}\text { The northern basin } & 4 \text { (MRAC } 99623-\end{array}$

$6 / 0$

$50 / 0$

$6 / 0$

$3(0-6) / 0$

Rumonge

( $3^{\circ} 58^{\prime} \mathrm{S}-29^{\circ} 25^{\prime} \mathrm{E}, \quad$ The northern basin 72 )

1.2. - 28.2.1935)

Ilagala

(05ำ $14^{\prime} \mathrm{S}-29^{\circ} 47^{\prime} \mathrm{E}$, The northern basin 8 (MRAC 89211 -

24.2.1947)

12 (MRAC 43763

72)

$7 / 0$

$50 / 0$

$7 / 0$

$3.5(0-7) / 0$

$18,41)$

Uvira $\left(3^{\circ} 22^{\prime} \mathrm{S}\right.$

$\left.29^{\circ} 09^{\prime} \mathrm{E}, 12.8 .2016\right)$ The northern basin $41(-)$

$41(-)$

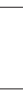

(1) $89211-$

$14 / 0$

$14 / 0 \quad 62.5 / 0 \quad 2.8 / 0 \quad 1.75(0-6) / 0$

\section{Stolothrissa} tanganicae

\begin{tabular}{|c|c|c|c|c|c|c|}
\hline $\begin{array}{l}\text { Bujumbura } \\
(4.8 .2016)\end{array}$ & The northern basin & $29(-)$ & 7 & 13.3 & 1.5 & $0.14(0-2)$ \\
\hline $\begin{array}{l}\text { Kalambo Lodge } \\
\left(8^{\circ} 59^{\prime} \mathrm{S}-31^{\circ} 18^{\prime} \mathrm{E},\right. \\
20.8 .2016)\end{array}$ & The southern basin & $48(-)$ & 6 & 4.2 & 1.5 & $0.06(0-2)$ \\
\hline $\begin{array}{l}\text { Kalemie (9.2.- } \\
10.2 .1947)\end{array}$ & The central basin & 6 (MRAC 89428-33) & 0 & 0 & 0 & 0 \\
\hline Kalemie (12.8.2016) & The central basin & $33(-)$ & 0 & 0 & 0 & 0 \\
\hline $\begin{array}{l}\text { Kigoma Bay } \\
(12.4 .-.13 .4 .1947)\end{array}$ & The northern basin & 4 (MRAC 89494-98) & & 0 & 0 & 0 \\
\hline $\begin{array}{l}\text { Kigoma Bay } \\
(13.5 .1947)\end{array}$ & The northern basin & 6 (MRAC 89462-65) & 5 & 33.3 & 2.5 & $2.5(1-4)$ \\
\hline $\begin{array}{l}\text { Mpulungu } \\
(4.7-5.7 .1965)\end{array}$ & The southern basin & $\begin{array}{l}7 \text { (MRAC 189618- } \\
\text { 19) }\end{array}$ & 0 & 0 & 0 & 0 \\
\hline $\begin{array}{l}\text { Mpulungu } \\
(3.10 .1966)\end{array}$ & The southern basin & $\begin{array}{l}2 \text { (MRAC 189595- } \\
601)\end{array}$ & 3 & 28.6 & 1.5 & $0.4(0-2)$ \\
\hline $\begin{array}{l}\text { Mpulungu } \\
(19.8 .2016)\end{array}$ & The southern basin & $18(-)$ & 2 & 11.1 & 1 & $0.11(0-1)$ \\
\hline $\begin{array}{l}\text { Musende Bay } \\
\left(8^{\circ} 46^{\prime} \mathrm{S}-31^{\circ} 06^{\prime} \mathrm{E},\right. \\
7.4 .1967)\end{array}$ & The southern basin & $\begin{array}{l}5 \text { (MRAC 190171- } \\
74)\end{array}$ & 4 & 20 & 3.5 & $0.8(0-4)$ \\
\hline Mvugo (15.8.2015) & The northern basin & $6(-)$ & 7 & 33.3 & 4 & $1.2(0-6)$ \\
\hline $\begin{array}{l}\text { Rumonge (1.1.- } \\
31.12 .1935)\end{array}$ & The northern basin & $\begin{array}{l}18 \text { (MRAC 43763- } \\
72)\end{array}$ & 28 & 61 & 3.5 & $1.55(0-7)$ \\
\hline $\begin{array}{l}\text { Utinta Bay } \\
\left(7^{\circ} 10^{\prime} \mathrm{S}-30^{\circ} 53^{\prime} \mathrm{E},\right. \\
17.2 .1947)\end{array}$ & The southern basin & 1 (MRAC 89442) & 1 & 100 & 1 & 1 \\
\hline Uvira (1.1.1935) & The northern basin & $\begin{array}{l}4 \text { (MRAC 43787- } \\
88,90,98)\end{array}$ & 0 & 0 & 0 & 0 \\
\hline Uvira (1.1.1954) & The northern basin & 2 (MRAC 99603-4) & 0 & 0 & 0 & 0 \\
\hline Uvira (12.8.2016) & The northern basin & $27(-)$ & 31 & 44 & 2.6 & $1.1(0-6)$ \\
\hline Uvira (12.8.2016) & The northern basin & $25(-)$ & 12 & 28 & 1.7 & $0.5(0-3)$ \\
\hline
\end{tabular}


the museum collection, Hoyer's medium. Some of the individuals were cut into three parts with the anterior and posterior parts mounted on slides and the rest used for genetic identification. Monogeneans selected for molecular analyses were transferred into Eppendorf tubes containing 99\% ethanol. Parasite identification and description were carried out using an Olympus BX51 microscope equipped with a drawing tube and OLYMPUS KL 1500 LED illumination. Fish tissue samples were deposited in the ichthyology collection of the RMCA under collection number MRAC P. 2016.20 and parasite voucher and type specimens are available in the invertebrate collection of the RMCA; the Finnish Museum of Natural History (MZH), Helsinki, Finland; the Iziko South African Museum (SAMC), Cape Town, Republic of South Africa; the Muséum national d'Histoire naturelle (MNHN), Paris, France; and the Natural History Museum (NHMUK), London, United Kingdom. Collected monogenean species were also compared to type material (MRAC MT. 35572 and 35711).

\section{Morphometrics}

All monogeneans found in this study were identified as representatives of Dactylogyridae. Since the taxonomy of dactylogyrids at species level is principally based on the morphology of their sclerotised structures (Pugachev et al., 2009; García-Varela et al., 2016), and since monogenean specimens could not be collected alive because the sardine hosts invariably die immediately upon capture (rendering staining of monogenean fresh specimens impossible), differential diagnoses focused on details of the parasites' hard parts. Measurements of sclerotized structures were taken at a magnification of $1000 \times$ using an Olympus BX51 microscope with incorporated phase contrast and the software Digital Image Analysis v4. In total, 25 different parameters regarding the total body size, the hard parts of haptoral and male copulatory organs (MCOs) were measured (see Fig. 2). Terminology was based on Řehulková et al. (2013). To check for inter-specific and intra-specific parasite phenotypic variability in haptor morphology, measurements were analysed by multivariate statistical techniques in the R package Adegenet (Jombart, 2008; R development core team, 2011), where principal component analysis (PCA) was conducted with standardised variables on the co-variance matrix of 21 morphological characters (total length and width of body, and the size of the sixth and seventh pair of marginal hooks were discarded because of the low number of observations). Outliers were identified and removed using Mahalanobis distances in the package mvoutlier (Filzmoser and Gschwandtner, 2017). To take possible geographical intra-specific variation into account, samples were grouped according to the three subbasins, following Danley et al. (2012). The effect of season (dry period from May to September, wet period from October to April), geography and host body size on haptoral morphometrics was tested using MANOVA, package stats (R Core Team, 2013), with Pillai's test of significance. To test the possible effect of host body size, fish specimens were assigned to three groups as follows (one group of sub-adults and one of adults for L. miodon (B and C) and S. tanganicae (A and B), respectively): A (4-6 cm), B (>6-9 cm), C $(>9 \mathrm{~cm})$ (Eccles, 1992). To avoid correlation between host size and any other parameter, specimens from one locality (Uvira and Kalemie, respectively) and

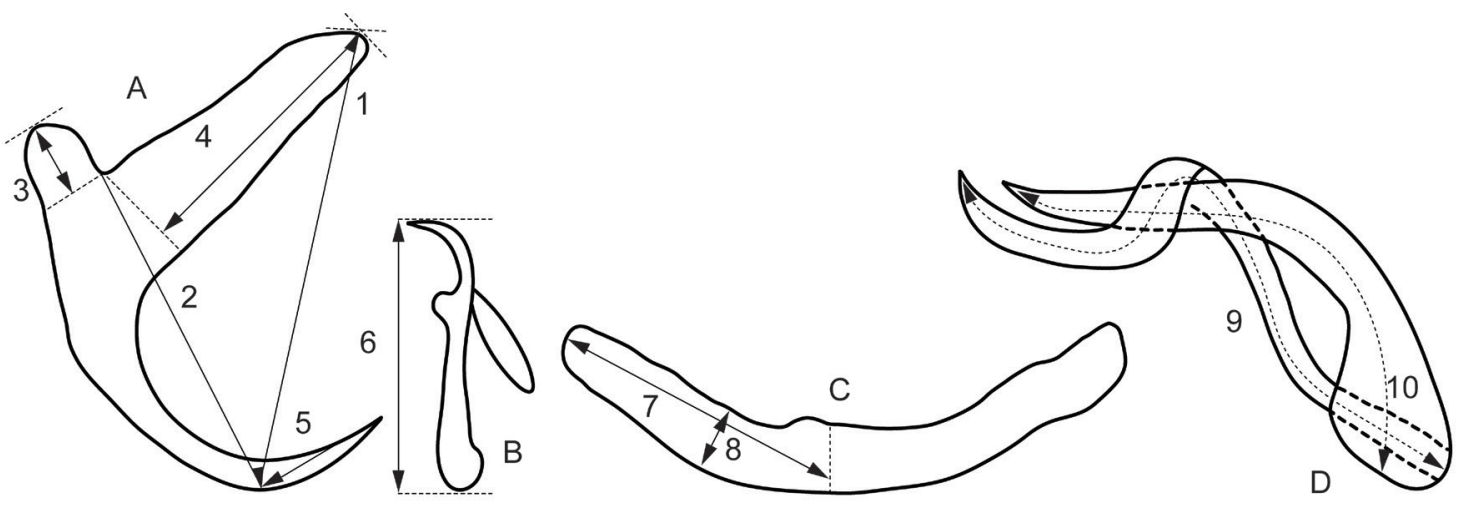

Figure 2. Measurements for sclerotized structures of haptor and reproductive organs of Kapentagyrus spp. A Anchor: 1 - Total length, 2-Length to notch, 3-Outer root length, 4-Inner root length, 5-Point length; B Hook: 6-length; C Bar: 7-Branch length, 8Branch width; D Male copulatory organ: 9-Copulatory tube length, 10-Accessory piece length. 
from the dry season were used for these analyses. The assumption of homogeneous variance within sample groups was verified by Levene's test. Two-sample T tests or non-parametric Mann-Whitney U tests (when the assumption of homogenous variance was not met) were performed to provide information about intraspecific variability in copulatory organ morphometric parameters related to host species, host size, season and geographic origin of all collected monogenean species.

\section{Molecular characterisation}

Species delimitation based on morphological characters was combined with genetic characterisation using tissue samples of a subset of the parasite individuals mentioned above and ribosomal DNA markers commonly used for dactylogyrid species delimitation. Specimens from all three sub-basins and both host species were included to investigate potential intra-specific genetic variation. Whole genomic DNA was extracted using the Qiagen Blood and Tissue Isolation Kit following the manufacturer's instructions with some modifications (samples in ATL buffer $(180 \mathrm{ml})$ with protein kinase (20 $\mathrm{ml}$ ) were kept in $1.5 \mathrm{ml}$ Eppendorf tubes overnight at room temperature). The DNA extract was concentrated to a volume of $80 \mathrm{ml}$ in $1.5 \mathrm{ml}$ Eppendorf tubes using a vacuum centrifuge and stored at a temperature of -20 ${ }^{\circ} \mathrm{C}$. To confirm parasite species delineation genetically, we used three different nuclear sequence fragments, from the small and large ribosomal subunit gene (18 and 28 rDNA) and the internal transcribed spacer 1 (ITS-1). Partial 18S rDNA together with ITS-1 were amplified using the S1 (5'-ATTCCGATAACGAACGAGACT-3') (Sinnappah et al., 2001) and Lig5.8R (5'-GATACTCGAGCCGAGTGATCC-3') (BlascoCosta et al., 2012) primers. Each reaction mix contained 1.5 unit of Taq Polymerase, $1 \mathrm{X}$ buffer containing 0.1 $\mathrm{mg} / \mathrm{ml} \mathrm{BSA}, 1.5 \mathrm{mM} \mathrm{MgCl}, 200 \mathrm{mM}$ dNTPs, $0.8 \mathrm{mM}$ of each primer and $3 \mu \mathrm{l}$ of isolated DNA (concentration was not measured) in a total reaction volume of 30 $\mu \mathrm{l}$ under the following conditions: $2 \mathrm{~min}$ at $95^{\circ} \mathrm{C}, 39$ cycles of $1 \mathrm{~min}$ at $95^{\circ} \mathrm{C}, 1 \mathrm{~min}$ at $55^{\circ} \mathrm{C}$ and $1 \mathrm{~min}$ and $30 \mathrm{~s}$ at $72{ }^{\circ} \mathrm{C}$, and finally $10 \mathrm{~min}$ at $72^{\circ} \mathrm{C}$. Primers C1 (5'-ACCCGCTGAATTTAAGCAT-3') and D2 (5'-TGGTCCGTGTTTCAAGAC-3') (Hassouna et al., 1984) were used for amplification of the partial 28S rDNA gene. Each PCR reaction contained 1.5 unit of Taq Polymerase, $1 \mathrm{X}$ buffer containing $0.1 \mathrm{mg} / \mathrm{ml}$ BSA, $1.5 \mathrm{mM} \mathrm{MgCl}, 200 \mathrm{mM}$ dNTPs, $0.5 \mathrm{mM}$ of each primer and $50 \mathrm{ng}$ of genomic DNA in a total reaction volume of $30 \mu \mathrm{l}$ under the following conditions: $2 \mathrm{~min}$ at $94{ }^{\circ} \mathrm{C}, 39$ cycles of 20 seconds at $94{ }^{\circ} \mathrm{C}, 30$ seconds at $58{ }^{\circ} \mathrm{C}$ and $1 \mathrm{~min}$ and $30 \mathrm{~s}$ at $72{ }^{\circ} \mathrm{C}$, and finally 10 min at $72{ }^{\circ} \mathrm{C}$. Amplification success was checked by agarose gel electrophoresis and positive samples were enzymatically cleaned up using $1 \mu \mathrm{l}$ of ExoSAP-IT reagent and $2.5 \mu 1$ of PCR product under the following conditions: $15 \mathrm{~min}$ at $37{ }^{\circ} \mathrm{C}$ and $15 \mathrm{~min}$ at $80^{\circ} \mathrm{C}$. After cycle sequencing of purified PCR products using the BigDye protocol v3.1, following the manufacturer's recommendations, fragments were cleaned up using the BigDye XTerminator® Purification Kit and visualized on an ABI3130 capillary sequencer. Electropherograms were visually inspected, corrected and sequences were aligned using MUSCLE (Edgar, 2004) under default distance measures as implemented in MEGA v7 (Kumar et al., 2016), together with previously published sequences of representative freshwater and marine dactylogyrid species (see Supplementary file 1: Table S1). The newly obtained sequences were deposited in NCBI GenBank under the accession numbers MH071782-83 and MH071807-8. For all sequenced loci, pairwise genetic distances (uncorrected p-distances) among all dactylogyrid species included in the phylogenetic reconstruction were calculated in MEGA v7.

\section{Phylogeny}

Phylogenetic analyses were based on three loci: 18S, 28S and ITS-1 rDNA. The consistency of all alignments was checked and corrected under the "automated 1" option in trimAL v1.2, which uses a heuristic search to find the best method for trimming the alignment (Capella-Gutiérrez et al., 2009). Alignment matrices of both ribosomal regions used for reconstruction of the dactylogyrid phylogeny were concatenated using Mesquite v3.2 (Maddison and Maddison, 2017).

Topali v2.5 (Milne et al., 2004) was used to select the most appropriate evolutionary model (based on the Bayesian information criterion) to be used in subsequent phylogenetic analyses. The GTR (Rodríguez et al., 1990) $+\Gamma+$ I model with a gamma shape parameter of 0.952 and a proportion of invariable sites I of 0.276 was used for the 28S rDNA region, the GTR $+\Gamma$ model with a gamma shape parameter of 0.222 was used for $18 \mathrm{~S}$ rDNA, and the HKY $+\Gamma$ model with a gamma shape parameter of 3.539 was used for the ITS-1 region. Phylogenetic analyses employed maximum likelihood (ML) and Bayesian inference (BI) in RAxML v8 (Stamatakis, 2014) and MrBayes v3.2.0 (Ronquist et al., 2012), respectively, 
Table 2. Results of MANOVA tests performed on haptoral measurements of Kapentagyrus limnotrissae and K. tanganicanus (haptoral morphologies from L. miodon and S. tanganicae, respectively). Only significant parameters are listed. Abbreviation of sub-basin in brackets: $\mathrm{N}$ - northern, $\mathrm{C}$ - central, $\mathrm{S}$ - southern.

\begin{tabular}{|c|c|c|c|c|c|c|c|}
\hline \multirow[b]{2}{*}{ Parameter } & \multicolumn{3}{|c|}{ K. limnotrissae } & \multicolumn{2}{|c|}{ K. tanganicanus (from L. miodon) } & \multicolumn{2}{|c|}{ K. tanganicanus (from S. tanganicae) } \\
\hline & Subbasin & Season & $\begin{array}{l}\text { Host body } \\
\text { size }\end{array}$ & Subbasin & Season & Season & Host body size \\
\hline \multicolumn{8}{|l|}{ Dorsal bar } \\
\hline \multirow{3}{*}{ Branch length } & 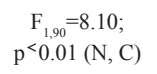 & & & & & & \\
\hline & $\begin{array}{c}\mathrm{F}_{1,42}=4.79 \\
\mathrm{p}^{<0.05}(\mathrm{~N}, \mathrm{~S})\end{array}$ & - & $\begin{array}{c}\mathrm{F}_{1,59}=18.19 ; \\
<0.001\end{array}$ & $\begin{array}{c}\mathrm{F}_{1,67}=10.10 \\
\mathrm{p}^{<0.01}\end{array}$ & $\begin{array}{c}\mathrm{F}_{1,73}=6.2 \\
\mathrm{p}^{<}<0.05\end{array}$ & $\begin{array}{c}\mathrm{F}_{1,61}=6.72 \\
\mathrm{p}^{<}<.05\end{array}$ & $\begin{array}{c}\mathrm{F}_{1,39}=6.54 \\
\mathrm{p}^{<}<.05\end{array}$ \\
\hline & $\begin{array}{c}F_{1,59}=18.18 \\
p^{<0} 0.001(S, C)\end{array}$ & & & & & & \\
\hline Thickness at midlength & - & - & - & - & - & - & $\begin{array}{c}\mathrm{F}_{1,39}=17.56 \\
\mathrm{p}^{<}<0.001\end{array}$ \\
\hline \multicolumn{8}{|l|}{ Ventral bar } \\
\hline Branch length & $\begin{array}{c}F_{1,59}=12.69 ; \\
p^{<} 0.001(S, C)\end{array}$ & & $\begin{array}{c}\mathrm{F}_{1,39}=12.69 ; \\
<0.001\end{array}$ & - & - & - & $\begin{aligned} \mathrm{F}_{1,39} & =12.50 \\
\mathrm{p} & <0.01\end{aligned}$ \\
\hline Branch maximum width & 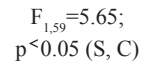 & $\begin{array}{c}\mathrm{F}_{1,100}=20.13 \\
\mathrm{p}^{<} 0.001\end{array}$ & $\begin{array}{c}\mathrm{F}_{1,59}=5.64 \\
\mathrm{p}^{<}<0.05\end{array}$ & - & - & $\begin{aligned} \mathrm{F}_{1,61} & =10.02 ; \\
\mathrm{p} & <0.05\end{aligned}$ & $\begin{aligned} \mathrm{F}_{1,39} & =21.14 \\
\mathrm{p}^{<} & <0.001\end{aligned}$ \\
\hline \multicolumn{8}{|l|}{ Hooks } \\
\hline Pair I & - & $\begin{array}{c}\mathrm{F}_{1,100}=17.18 \\
\mathrm{p}^{<} 0.001\end{array}$ & - & $\begin{array}{c}\mathrm{F}_{1,66}=5.58 \\
\mathrm{p}^{>}=0.05\end{array}$ & $\begin{array}{c}\mathrm{F}_{1,73}=3.97 \\
\mathrm{p}^{<} 0.05\end{array}$ & - & - \\
\hline Pair II & - & - & - & $\begin{array}{c}\mathrm{F}_{1,66}=5.82 \\
\mathrm{p}^{<}<.05\end{array}$ & - & & $\begin{array}{c}\mathrm{F}_{1,39}=6.36 \\
\mathrm{p}^{<}\end{array}$ \\
\hline Pair III & - & - & - & - & - & $\begin{array}{c}\mathrm{F}_{1,61}=4.03 ; \\
\mathrm{p}<0.05\end{array}$ & $\begin{array}{c}\mathrm{F}_{1,33}=5.76 \\
\mathrm{p}^{<}\end{array}$ \\
\hline Pair V & - & - & - & - & - & $\begin{array}{c}\mathrm{F}_{1,66}=5.43 \\
\mathrm{p}^{<}<.05\end{array}$ & $\begin{aligned} \mathrm{F}_{1,39} & =8.28 \\
\mathrm{p}^{<} & 0.01\end{aligned}$ \\
\hline Pair VI & - & - & - & $\begin{aligned} \mathrm{F}_{1,67} & =8.77 \\
\mathrm{p} & <0.01\end{aligned}$ & $\begin{array}{c}\mathrm{F}_{1,73}=5.41 \\
\mathrm{p}^{<}<.05\end{array}$ & - & - \\
\hline Pair VII & - & - & - & - & - & - & $\begin{array}{c}\mathrm{F}_{1,39}=6.25 \\
\mathrm{p}<0.05\end{array}$ \\
\hline \multicolumn{8}{|l|}{ Dorsal anchor } \\
\hline Inner root length & - & - & - & $\begin{aligned} \mathrm{F}_{1,67} & =10.10 \\
\mathrm{p} & <0.01\end{aligned}$ & $\begin{array}{c}\mathrm{F}_{1,73}=10.5 \\
\mathrm{p}^{>} 0.01\end{array}$ & - & - \\
\hline Length to notch & 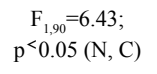 & - & - & - & - & - & - \\
\hline \multicolumn{8}{|l|}{ Ventral anchor } \\
\hline Inner root length & - & $\begin{array}{c}\mathrm{F}_{1,100}=4.8 \\
\mathrm{p}^{<}<0.05\end{array}$ & - & $\begin{array}{c}\mathrm{F}_{1,67}=9.98 \\
\mathrm{p}^{<}<0.01\end{array}$ & $\begin{array}{c}\mathrm{F}_{1,73}=10.1 \\
\mathrm{p}^{>} 0.01\end{array}$ & - & - \\
\hline Outer root length & - & - & - & $\begin{aligned} \mathrm{F}_{1,66} & =6.00 \\
\mathrm{p}^{<} & <0.05\end{aligned}$ & $\begin{array}{c}\mathrm{F}_{1,73}=5.2 \\
\mathrm{p}^{>} 0.05\end{array}$ & - & - \\
\hline Length to notch & 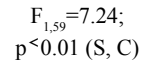 & - & $\begin{array}{c}\mathrm{F}_{1,59}=7.24 \\
\mathrm{p}^{<}<.01\end{array}$ & - & - & - & - \\
\hline
\end{tabular}

with data partitioned per marker. The ML tree search was conducted using RAxML's standard tree search algorithm and bootstrap support was calculated using the option with an automated number of replicates to obtain stable support values under the frequency stopping criterion (Stamatakis, 2014). Bayesian inference in MrBayes was based on two independent runs $\left(10^{7}\right.$ generations, sampled every $1,000^{\text {th }}$ generation and with a burn-in of $10 \%$ ). Parameter convergence and run stationarity were assessed in Tracer v1.6 (Rambaut et al., 2014). As Dactylogyridae and Diplectanidae were shown to be sister taxa (Šimková et al., 2003), sequences of Diplectanum aequans (Wagener, 1857), 1991 were used as outgroup. To compare the 
genetic diversity within dactylogyrid genera in Lake Tanganyika, sequences of Cichlidogyrus Paperna, 1960 species infecting cichlids from the lake's pelagic zone (C. attenboroughi, C. brunnensis Kmentová, Gelnar, Koblmüller and Vanhove, 2016 and C. casuarinus Pariselle, Muterezi Bukinga and Vanhove, 2015) as well as a sequence of a littoral species of Cichlidogyrus (C. irenae Gillardin, Vanhove, Pariselle, Huyse and Volckaert, 2012) were included. Phylogenetic trees were edited in FigTree v1.4.2 (http://tree.bio.ed.ac.uk/ software/figtree).

\section{Results}

Monogenean species records and description

In total, 406 monogenean specimens were recorded from two host species, namely L. miodon (300) and S. tanganicae (106) (Table 1). Morphological characterisation revealed the presence of two monogenean species belonging to a newly described genus, Kapentagyrus Kmentová, Gelnar and Vanhove, gen. nov. The existence of Kapentagyrus as a new genus is supported by phylogenetic reconstruction at the family level (Fig. 4) and its description is provided in Appendix. The previously described species Ancyrocephalus limnotrissae is reassigned to this new genus. The two species of Kapentagyrus in Lake Tanganyika can be morphologically distinguished by the proportion of inner/outer root length of both ventral and dorsal anchors (around 3 in K. limnotrissae Kmentová, Gelnar and Vanhove comb. nov., whereas this proportion is close to 2 in $K$. tanganicanus Kmentová, Gelnar and Vanhove, sp. nov.). Only one species, described in this study as $K$. tanganicanus, was collected from $S$. tanganicae. Limnothrissa miodon was infected by both $K$. tanganicanus and by the host-specific monogenean species $K$. limnotrissae. Due to the bad state of the holotype, a redescription of this species is provided as the type species of the newly described genus in Appendix, together with the description of $K$. tanganicanus. Infection parameters are shown in Table 1. Considering morphological and morphometric differences, especially in the total length of both anchors and in the branch length of the dorsal bar (see Appendix, Table 3), phenotypic variability related to host species identity in $K$. tanganicanus. is described (see Table 3, Figs 7 and 8). Even though these intraspecific morphological and morphometric differences are of the same magnitude as the interspecific distances (Fig. 3 and Table 3), ribosomal DNA sequences in all three regions were identical for all individuals assigned to $K$.tanganicanus. Therefore, we consider the individuals infecting $L$. miodon and $S$. tanganicae as belonging to the same species.

\section{Morphometrics}

Interspecific and between-host level

Principal component analysis was performed to examine and visualise the morphometric differences between $K$. limnotrissae and the two haptor morphologies of $K$. tanganicanus. The analysis was done using haptoral morphometric parameters of 96 individuals of $K$. limnotrissae. including the holotype, and on 58 and 69 individuals of $K$. tanganicanus collected from $S$. tanganicae and L. miodon, respectively. The first PC explained $33.0 \%$ and the second $16.3 \%$ of the variation in the dataset. Results show a strong separation of three groups (Fig. 3). The combination of both PCA axes chiefly described host species identity of $K$. tanganicanus, resulting in two distinct haptoral morphologies. The first axis separated specimens of $K$. limnotrissae and $K$. tanganicanus, both parasitizing on L. miodon. The type specimen of $K$. limnotrissae clustered with the rest of the measured individuals of this species, hereby confirming species identification (Fig. 3). Mann-Whitney U tests showed a significantly larger copulatory tube and accessory piece in $K$. limnotrissae than in $K$. tanganicanus (copulatory tube $-\mathrm{Z}_{1.80}=-9.90 ; \mathrm{p}<0.001$; accessory piece $-\mathrm{Z}_{1.78}=-$ $9.52 ; p<0.001)$, hereby confirming species delineation. There was no difference in copulatory tube length between specimens of $K$. tanganicanus collected from different host species, but the accessory piece was longer in individuals collected from L. miodon than in individuals from S.tanganicae (Mann Whitney U test; $\left.\mathrm{Z}_{1,77}=-3.31 ; \mathrm{p}<0.001\right)$.

Intra-specific level: influence of season, sub-basin and host size

Intraspecific morphometric variation was analysed by MANOVA. In K. limnotrissae two of the 21 parameters, namely inner root length of the dorsal anchor and length of the first marginal hook, were significantly larger in specimens collected during the dry compared to specimens collected during the rainy season, while the maximum straight width of the ventral bar was significantly smaller in the dry compared to the rainy 
Table 3. Comparison of measurements performed on Kapentagyrus limnotrissae haptoral and genital hard parts described in Paperna (1973), Kapentagyrus limnotrissae redescribed in this study and K. tanganicanus (a - mean value \pm standard deviation, $\mathrm{b}-$ range).

\begin{tabular}{|c|c|c|c|c|}
\hline Parameters $(\mu \mathrm{m})$ & $\begin{array}{c}\text { K. limnotrissae } \\
\text { (original } \\
\text { description) }\end{array}$ & $\begin{array}{l}\text { K. limnotrissae } \\
\text { (present study) }\end{array}$ & $\begin{array}{l}\text { K. tanganicanus } \\
(\text { L. miodon })\end{array}$ & $\begin{array}{l}\text { K. tanganicanus } \\
(S . \text { tanganicae })\end{array}$ \\
\hline Total length & $440-610$ & $458.1 \pm 128.5(n=21) ;(286.2-748.3)$ & $214.2 \pm 39.6(n=23) ;(121.7-285.8)$ & $167.9 \pm 25.57(n=20) ;(146.8-199.4)$ \\
\hline Total width & $90-130$ & $143.9 \pm 26.2(n=20) ;(97.8-220.3)$ & $779.5 \pm 170.1(n=25) ;(474.4-1171.3)$ & $565.5 \pm 122.55(n=4) ;(462.7-710.9)$ \\
\hline \multicolumn{5}{|l|}{ Ventral anchor } \\
\hline Total length & $20-27$ & $26.2 \pm 1.5(\mathrm{n}=99) ;(22.3-31.8)$ & $31.6 \pm 2.4(n=77) ;(25.3-36.7)$ & $19.4 \pm 1.8(n=42) ;(15.3-24.6)$ \\
\hline Length to notch & $19-20$ & $18.8 \pm 1.6(n=98) ;(15.5-28.3)$ & $21.3 \pm 1.8(\mathrm{n}=72) ;(16.5-26.7)$ & $24.3 \pm 2.4(\mathrm{n}=41) ;(19-32.8)$ \\
\hline Inner root length & $7-13$ & $15.6 \pm 1.4(\mathrm{n}=99) ;(11.4-18.6)$ & $18.6 \pm 2.5(n=77) ;(10.0-22.9)$ & $13.0 \pm 2.1(n=41) ;(9.0-18.2)$ \\
\hline Outer root length & $5-8$ & $5.0 \pm 0.8(\mathrm{n}=94) ;(3.6-7.9)$ & $8.7 \pm 1.5(n=75) ;(4.9-11.4)$ & $6.6 \pm 1.1(n=43) ;(4.3-9.8)$ \\
\hline Point length & $5-7$ & $8.1 \pm 1.1(\mathrm{n}=90) ;(5.3-11.0)$ & $8.7 \pm 1.1(n=69) ;(6.7-12.3)$ & $7.7 \pm 1.3(n=39) ;(5.0-10.5)$ \\
\hline \multicolumn{5}{|l|}{ Dorsal anchor } \\
\hline Total length & $23-26$ & $21.48 \pm 1.55(\mathrm{n}=88) ;(18.7-26.1)$ & $27.7 \pm 2.0(n=73) ;(20.832 .6)$ & $21.5 \pm 1.96(n=40) ;(17.5-26.2)$ \\
\hline Length to notch & $15-19$ & $16.5 \pm 1.3(\mathrm{n}=87) ;(13.8-20.5)$ & $19.9 \pm 2.1(\mathrm{n}=74) ;(13.4-28.2)$ & $17.9 \pm 1.16(40) ;(15.3-21.5)$ \\
\hline Inner root length & $10-13$ & $11.2 \pm 1.3(n=87) ;(7.8-14.6)$ & $14.4 \pm 2.3(n=72) ;(6.6-20.6)$ & $10.5 \pm 1.42(\mathrm{n}=40) ;(7.7-14.8)$ \\
\hline Outer root length & $5-7$ & $4.5 \pm 1.0(\mathrm{n}=84) ;(2.5-8.0)$ & $8.1 \pm 1.6(n=70) ;(4.9-16.1)$ & $5.8 \pm 0.89(n=39) ;(4.2-7.8)$ \\
\hline Point length & $5-7$ & $7.8 \pm 1.1(\mathrm{n}=84) ;(5.1-10.9)$ & $8.2 \pm 1.2(n=67) ;(5.7-11.4)$ & $7.5 \pm 0.98(n=38) ;(5.9-9.6)$ \\
\hline \multicolumn{5}{|l|}{ Ventral bar } \\
\hline Branch length & $27-35$ & $16.7 \pm 3.0(n=84) ;(12.5-33.3)$ & $21.4 \pm 3.7(n=66) ;(14.5-32.7)$ & $18.9 \pm 3.10(n=40) ;(14.2-27.8)$ \\
\hline $\begin{array}{l}\text { Branch maximum } \\
\text { width }\end{array}$ & - & $4.4 \pm 0.7(n=86) ;(3.0-7.0)$ & $7 \pm 1.5(n=72) ;(3.9-11.4)$ & $4.8 \pm 1.28(\mathrm{n}=40) ;(3.0-7.7)$ \\
\hline \multicolumn{5}{|l|}{ Dorsal bar } \\
\hline Branch length & $22-35$ & $17.4 \pm 3(n=69) ;(12.0-27.1)$ & $25.1 \pm 4.1(n=72) ;(18.4-35.2)$ & $20.8 \pm 3.23(n=39) ;(14.9-28.7)$ \\
\hline $\begin{array}{l}\text { Thickness at } \\
\text { midlength }\end{array}$ & - & $4.2 \pm 0.7(\mathrm{n}=75) ;(2.9-6.3)$ & $6.8 \pm 1.3(n=75) ;(4-10)$ & $4.9 \pm 4.94(n=41) ;(3.7-7.5)$ \\
\hline \multicolumn{5}{|l|}{ Hooks } \\
\hline Pair I & - & $14.4 \pm 1.4(\mathrm{n}=67) ;(11.4-17.9)$ & $13.3 \pm 1.3(\mathrm{n}=63) ;(10.0-17.8)$ & $12.8 \pm 1.17(n=38) ;(9.7-15.7)$ \\
\hline Pair II & - & $15.4 \pm 1.3(\mathrm{n}=63) ;(12.1-18.2)$ & $14.6 \pm 1.6(\mathrm{n}=47) ;(11.8-17.9)$ & $13.5 \pm 1.22(n=32) ;(10.8-15.8)$ \\
\hline Pair III & - & $15.9 \pm 1.2(\mathrm{n}=68) ;(13.3-19.3)$ & $14.8 \pm 1.5(\mathrm{n}=53) ;(11.2-17.7)$ & $13.7 \pm 1.08(\mathrm{n}=33) ;(12-16.1)$ \\
\hline Pair IV & - & $16.2 \pm 1.1(\mathrm{n}=59) ;(13.0-19.3)$ & $15.3 \pm 1.6(n=42) ;(10.8-19.4)$ & $13.8 \pm 1.60(n=31) ;(11.3-16.2)$ \\
\hline Pair V & - & $14.2 \pm 1.6(n=35) ;(9.3-17)$ & $13.5 \pm 1.4(n=32) ;(10.4-16.2)$ & $5.8 \pm 0.89(n=39) ;(4.2-7.8)$ \\
\hline Pair VI & - & $16.3 \pm 1.1(n=34) ;(13.0-18.8)$ & $15.3 \pm 1.4(\mathrm{n}=32) ;(11.9-18.1)$ & $14.6 \pm 0.92(n=25) ;(12.0-15.9)$ \\
\hline Pair VII & - & $16,7 \pm 1,4(n=24) ;(14,3-20,8)$ & $15 \pm 1,3(n=22) ;(12,9-17,5)$ & $13,8 \pm 0,97(\mathrm{n}=16) ;(11,0-15,5)$ \\
\hline $\begin{array}{l}\text { Pair I, II, III, IV, VI, } \\
\text { VII average size }\end{array}$ & $13-15$ & $15,5 \pm 1,5(n=350) ;(9,3-20,8)$ & $14,6 \pm 1,6(n=259) ;(10,0-19,4)$ & $13,6 \pm 1,2(\mathrm{n}=174) ;(9,7-16,2)$ \\
\hline $\begin{array}{l}\text { Copulatory tube } \\
\text { curved length }\end{array}$ & $21-23$ & $30,4 \pm 2,5(n=75) ;(25,1-38,3)$ & $39,7 \pm 4,6(n=63) ;(30,4-49,9)$ & $38,1 \pm 2,27(n=12) ;(33,7-42,2)$ \\
\hline $\begin{array}{l}\text { Accessory piece } \\
\text { curved length }\end{array}$ & - & $36,1 \pm 3,6(n=69) ;(28,0-47,1)$ & $52,5 \pm 6,0(n=62) ;(33,9-62,6)$ & $45,9 \pm 4,2(n=12) ;(38,3-53,5)$ \\
\hline
\end{tabular}


season. Moreover, some of the parameters also showed significant differences in relation to the geographic origin of the specimens. An extended length from the point to the notch of the dorsal anchor and an extended branch length of the dorsal bar were seen in specimens from the northern compared to those from the central sub-basin, while the branch length of the dorsal bar of specimens from the northern sub-basin is shorter compared to specimens from the southern sub-basin. An extended length of four other parameters: branch length of the dorsal bar, branch length of the ventral bar, maximum width of the ventral bar and length to notch of the ventral anchor was documented in specimens from the southern compared to those from the central sub-basin. Significantly higher length of the branch of the dorsal bar, length to notch of the ventral anchor and branch length and maximum width of the ventral bar were reported in specimens stemming from the larger size class of host specimens of L. miodon. There were no significant differences in copulatory tube parameters between specimens of $K$. limnotrissae collected in different seasons or from different sub-basins.

In $K$. tanganicanus, phenotypic variability related to host species was found. Hence, the relation of morphometric parameters to season, sub-basin and host size was tested separately for specimens collected from $L$. miodon and $S$. tanganicae. Similar to the situation in K. limnotrissae, the inner root length of the dorsal anchor of $K$. tanganicanus collected from L. miodon was larger in the dry compared to the rainy season, as were the inner and outer root lengths of the ventral anchor. On the other hand, the length of the dorsal bar branch and of the first and sixth marginal hook was larger in the rainy compared to the dry season. An extended length of the dorsal's bar branch, the third and fifth marginal hook and a thicker ventral bar was reported in the rainy compared to the dry season in $K$. tanganicanus collected from S. tanganicae. Since there were not enough specimens from the central and southern sub-basin of $K$. tanganicanus collected from $S$. tanganicae, the influence of geographic origin could only be tested on specimens collected from L. miodon. Similar to K. limnotrissae, geographical differences were reflected in an extended branch length of the dorsal bar in the northern compared to the southern part of the lake for K. tanganicanus. Moreover, the length of the dorsal and ventral anchor inner root, the ventral anchor outer root and the first, second and sixth marginal hook significantly differed between sub-basins. While there was no indication of any morphometric parameter being influenced by host size in the case of parasites of
L. miodon, significantly larger haptoral structures were found in parasites collected from larger specimens of $S$. tanganicae: branch length and width of the dorsal bar; branch length and maximum width of the ventral bar; length of the second, third, sixth and seventh marginal hook. The complete list of significant results of MANOVA tests is given in Table 2.

Analyses testing for the influence of season and geographic origin on the MCO of $K$. tanganicanus were conducted only on specimens collected from $L$. miodon. The copulatory tube was shorter in specimens collected in the dry season than in those collected in the rainy season (copulatory tube, $\mathrm{t}$-test $-\mathrm{t}_{1,46}=3.87$; $\mathrm{p}<0.001)$. Individuals from the central sub-basin were omitted from the analyses because of the small sample size. There was no significant difference between specimens from the northern and southern basin in measurements of the MCO.

\section{Genetic characterisation}

To study genetic diversity within and between the parasite species under consideration, markers with different rates of molecular evolution were used. Sequences of three nuclear rDNA regions were obtained from five sequenced individuals for each species, sub-basin and marker. The length of the successfully sequenced 28S rDNA fragment was 643 base pairs (bp). The 18S rDNA and ITS-1 fragments were 459 and 321 bp long, respectively. Uncorrected p-distances between the two species of Kapentagyrus amounted to $0.9 \%, 0.2 \%$ and $4 \%$ in $28 \mathrm{~S}, 18 \mathrm{~S}$ and ITS1 rDNA fragments, respectively. The difference of $4 \%$ in the ITS- 1 region is well above the proposed $1 \%$ cutoff between species for the best-studied monogenean genus, Gyrodactylus von Nordmann, 1832 (Ziętara and Lumme, 2002). Hence, the presence of two species, $K$. limnotrissae and $K$.tanganicanus, was also confirmed genetically. No genetic differences were found among individuals assigned to $K$. tanganicanus, suggesting that the two observed haptoral morphologies are the result of phenotypic variability among conspecifics.

Phylogenetic affinities of monogenean genera

Both ML and BI produced the same tree topologies. The alignment combined fragments of 28S, $18 \mathrm{~S}$ and ITS-1 of 34 species (see Supplementary file 1: Table S1) for a total of $1388 \mathrm{bp}$. The species of Kapentagyrus reported in our study formed a well-supported monophyletic lineage within Dactylogyridae and did not show any 


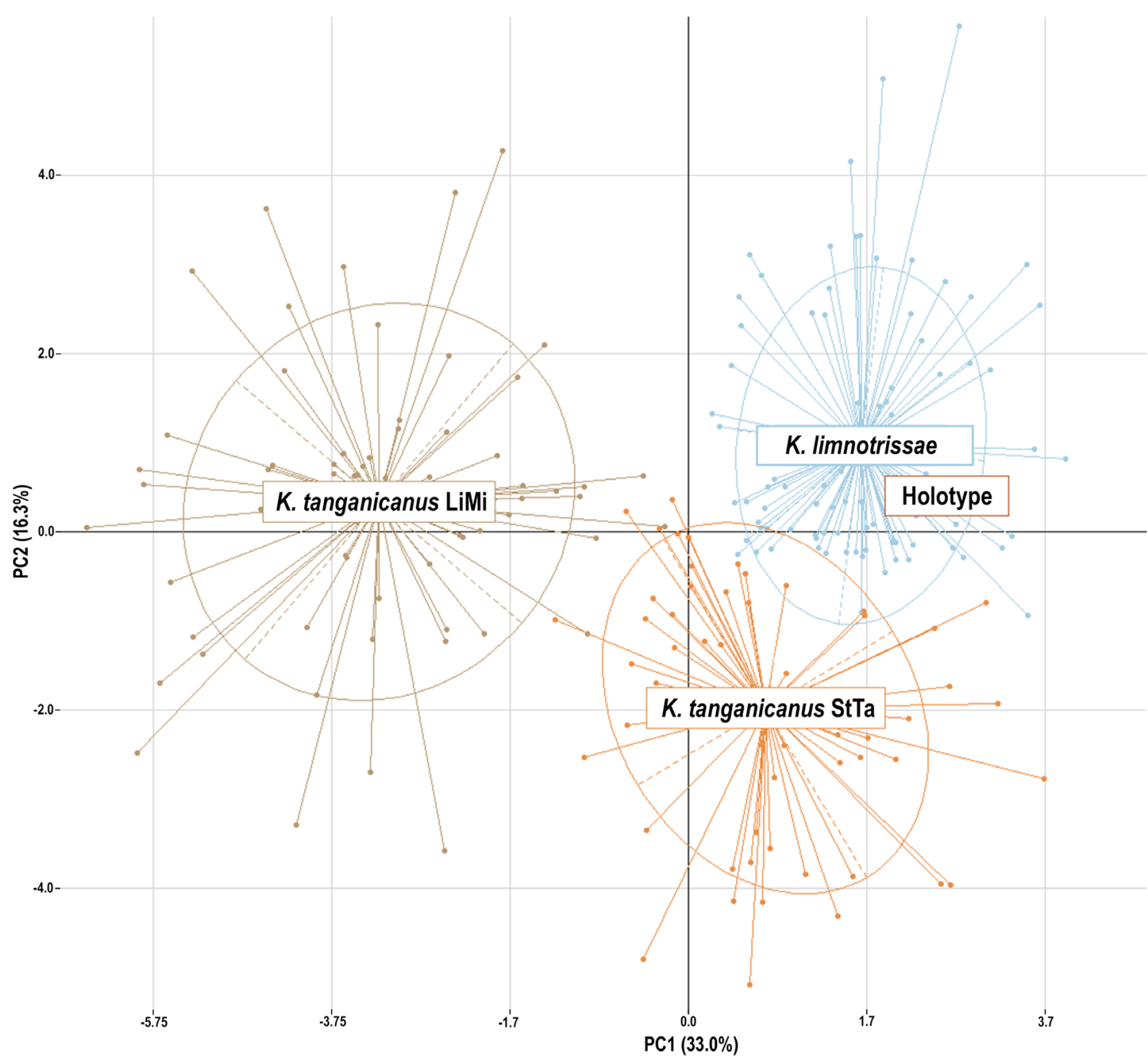

Figure 3. A biplot of PCA (first two axes) based on measurements of haptoral sclerotized structures of Kapentagyrus limnotrissae and K. tanganicanus. Ellipses indicate the distribution of the individuals from different groups centred by the mean value. The position of the holotype of $K$. limnotrissae and of two phenotypes of $K$. tanganicanus separated by host species, LiMi - L. miodon, StTa - S. tanganicae are indicated separately.

phylogenetic affinity to the type species of the genus Ancyrocephalus, Ancyrocephalus paradoxus Creplin, 1839, or any other monogenean lineage (Fig. 4). The phylogenetic analysis therefore supports Kapentagyrus as a new genus of Dactylogyridae. Low support values were observed at deeper phylogenetic levels.

\section{Discussion}

This is the first comprehensive study of the monogenean fauna of two of the most economically important fish species in Lake Tanganyika, using a combination of historical and recently collected host specimens. A new monogenean genus of Dactylogyridae is described as Kapentagyrus with two species: Kapentagyrus limnotrissae and Kapentagyrus tanganicanus, recorded in this study. The latter, newly discovered species, shows phenotypic variability in relation to its host species, but conspecificity of both phenotypes was confirmed by genetic data. Analyses on morphometric data were performed to test the effect of a range of factors on parasite morphology. The species' phylogenetic affinities were inferred at the family level. 


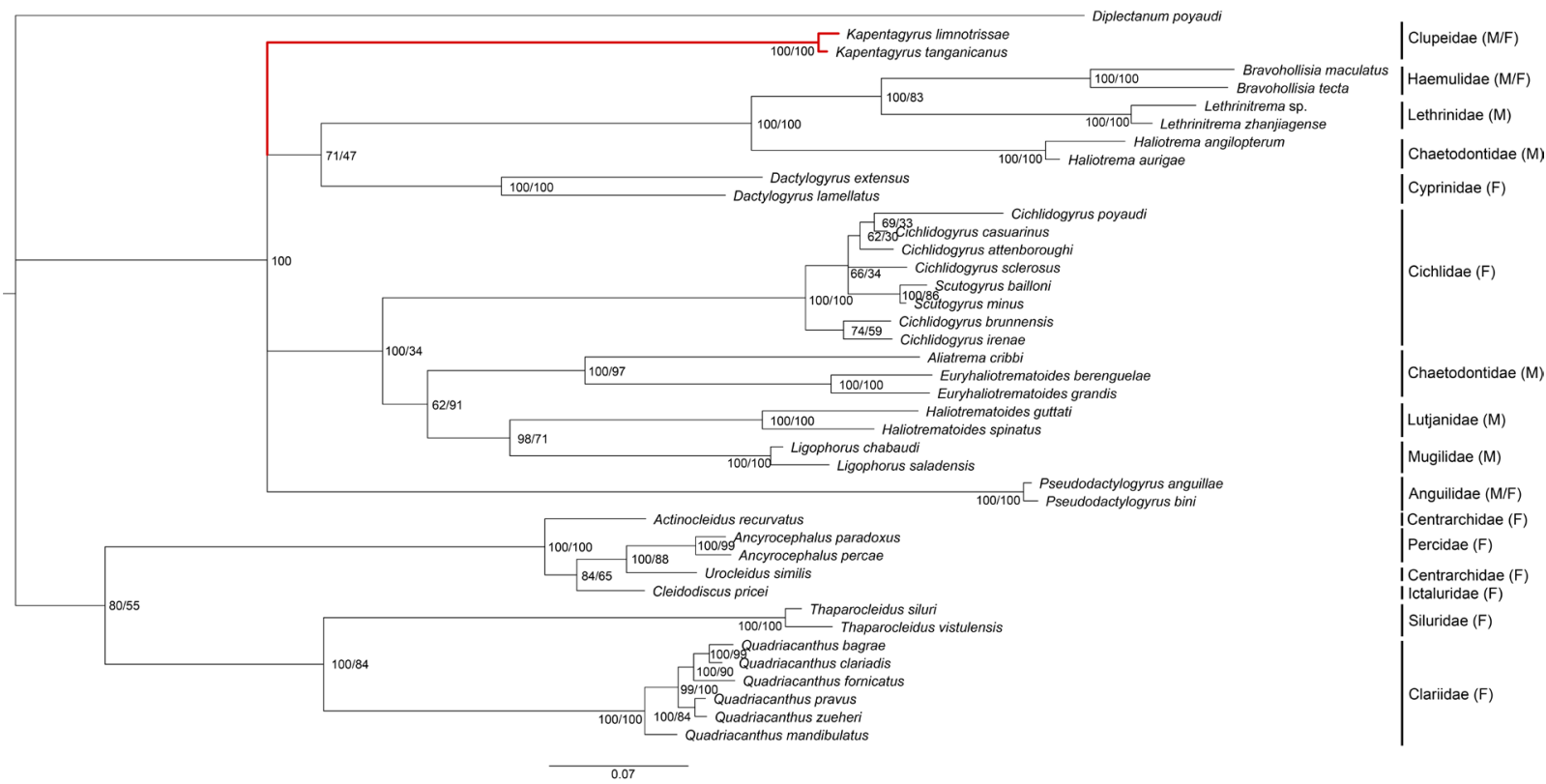

Figure 4. Bayesian inference phylogram based on 28S, 18S and ITS-1 rDNA fragments from 34 haplotypes of different dactylogyrid species. Bootstrap percentages for maximum likelihood (before slashes) and posterior probabilities for Bayesian inference (behind slashes) are shown. Host families together with their marine $(\mathrm{M})$ or freshwater lifestyle (F), respectively, are specified behind vertical lines. The scale bar indicates the expected number of substitutions per site.

\section{Monogenean species infecting sardines in Lake Tanganyika}

The two dactylogyrid monogenean species infecting clupeids inLakeTanganyikaareplaced in Kapentagyrus. The previously described species infecting L. miodon, Ancyrocephalus limnotrissae was reassigned to the new genus. The group of monogeneans referred to as Ancyrocephalus sensu lato with A. paradoxus as the type species is characterised by an S-shaped copulatory tube longer than $7 \mu \mathrm{m}$ with a triangular accessory piece and anchors with a broad base and a short point (Pugachev et al., 2009). Although the copulatory tube of the species of Kapentagyrus infecting L. miodon and S. tanganicae corresponds to this characterisation, the shape of their anchors, their elongated accessory piece and the presence of a single seminal vesicle and prostatic gland, do not conform to this diagnosis (see Appendix). Moreover, our phylogenetic analysis of Dactylogyridae show that species belonging to Ancyrocephalus sensu stricto (A. paradoxus and A. percae Ergens, 1966) do not cluster with the species collected in this study (Fig. 4). Together with the apparent morphological differences with the type species of Ancyrocephalus, A. paradoxus, this shows polyphyly of Ancyrocephalus and justifies the proposal of a new genus of dactylogyrids infecting African freshwater clupeids, described as Kapentagyrus. Other species of Ancyrocephalus have been described from non-clupeid African fish: A. barilli Paperna, 1973 from the cyprinid Raiamas senegalensis (Steindachner, 1870) and A. claveaui Birgi, 1988 from the poeciliid Poropanchax luxopthalmus (Brüning, 1929). Based on their morphology neither of these species belong to Kapentagyrus or to Ancyrocephalus sensu stricto. Ancyrocephalus sensu lato can be considered as a catch-all genus and therefore a formal revision is needed (Pugachev et al., 2009). The monogenean described from the clupeid Pellonula leonensis Boulenger, 1916 is morphologically very similar to those infecting clupeids in Lake Tanganyika and is therefore reassigned to Kapentagyrus as K. pellonulae comb. nov. (Paperna, 1969). Interestingly, the three species of Kapentagyrus described from African clupeids ( $K$. limnotrissae, $K$. tanganicanus and $K$. pellonulae) share a highly similar MCO that differs only slightly in size.

While the general morphology of monogenean haptoral sclerites is often believed to represent variation at the genus or family level, the shape and size of copulatory organs is considered to be speciesspecific (Pugachev et al., 2009). Although differences 
in the shape and size of haptoral hard parts between the two Lake Tanganyika species of Kapentagyrus are evident and were also clearly visible in a PCA plot (see Fig. 3, Table 3), no structural morphological difference except a size difference was seen in the MCO. This discrepancy has been previously reported in other monogenean species belonging to Pseudorhabdosynochus Yamaguti, 1958 (Sigura and Justine, 2008) and Cichlidogyrus (Messu Mandeng et al., 2015). This is supposed to be influenced by the degree of host genetic differentiation correlated with the age of the parasite lineage (Poulin, 1992, 2007; Poulin and Morand, 2004). Hence this may be linked to the recent divergence of the two species of Kapentagyrus on Tanganyika clupeids, indicated by their low interspecific genetic distances. The morphology of copulatory organs therefore does not seem to be the only reproductive isolation mechanism in dactylogyrids; indeed, reproductive isolation of conspecific monogeneans was suggested to be a result of microhabitat specialisation (Šimková et al., 2006). Despite the lack of shape differences in the MCO between $K$. limnotrissae and $K$. tanganicanus, significant morphometric differences in both tested traits (copulatory tube and accessory piece length) point towards a reproductive barrier in these two sympatric monogenean species, as was confirmed by genetic characterisation.

The morphology-based delineation of the collected monogenean species was confirmed by all three analysed ribosomal DNA regions. No genetic intraspecific variability related to host species identity or geographical origin was detected. Recent divergence among the species of Kapentagyrus from Lake Tanganyika is indicated by the low genetic distances obtained for all three genetic markers analysed $(0.9 \%$, $0.2 \%$ and $4 \%$ in $28 \mathrm{~S}, 18 \mathrm{~S}$ and ITS- 1 rDNA fragments, respectively) compared to species of Cichlidogyrus (5.6\%, 2.6\% and $15.8 \%$ in $28 \mathrm{~S}, 18 \mathrm{~S}$ and ITS- 1 rDNA fragments, respectively), the other dactylogyrid lineage present in the pelagic waters of Lake Tanganyika (sequences part of this study).

While a similar prevalence was observed for both monogenean species parasitizing on L. miodon (35\% for $K$. limnotrissae and $40 \%$ for $K$. tanganicanus), a lower prevalence was found for $K$. tanganicanus on $S$. tanganicae (18\%). This pattern might be explained by the more pelagic lifestyle and shorter lifespan of $S$. tanganicae (Mulimbwa and Shirakihara, 1994) making attachment of monogenean larvae more difficult as this is considered to be more successful in the littoral and benthic zones (Kearn,1967). Moreover, there appeared to be geographical differences in the prevalence of $K$. tanganicanus on $S$. tanganicae, with higher values in the northern part (36\%), compared to the central (0\%) and southern parts of the lake $(4.3 \%)$ (data from the dry season). This result could be correlated with the lower abundance of S. tanganicae in the southern part of the lake (Mannini et al., 1996) and therefore lower opportunities for parasites to infect this fish species (Bagge et al., 2004). However, only little is known about the spatial dynamics of clupeid demographics (Mulimbwa and Shirakihara, 1994). Unfortunately, due to a lack of samples, seasonal variation in prevalence could not be tested in L. miodon. Interestingly, low infection intensity was observed in both monogenean species, ranging from one to 11 individuals. This result could be explained by a combination of the mostly pelagic lifestyle of clupeids preventing multiple infections, which are proposed to occur in the littoral zone (Rohde et al., 1995) and the small size of the host species (Poulin, 2000).

\section{Intra-specific morphological variability}

The PCA revealed morphometric variation in haptoral sclerites in $K$. tanganicanus that was related to host species. Such intra-specific variability is commonly reported in monogeneans (Šimková et al., 2001a; KaciChaouch et al., 2008; Mladineo et al., 2013; Kmentová et al., 2016). Based on Fankoua et al., (2017), the shape and size of monogenean sclerotised structures could also be affected by the type of mounting medium. However, such an influence was minimized in our study by using GAP as well as Hoyer's medium for specimens from both host species. Remarkably, in this study, inter- and intra-specific morphological variation were of a similar magnitude (see Fig. 3). This situation is probably correlated with an adaptation to host habitat confirming results from previous studies showing greater morphometric variability of generalist species compared to specialists (Šimková et al., 2001a; Kaci-Chaouch et al., 2008). Since the MCO starts to develop once the haptor is fully developed (Kearn, 1968; Sanchez-Garcia et al., 2015), all collected specimens were considered adults. Hence, the observed differences in haptoral measurements of specimens with developed $\mathrm{MCO}$ between the rainy and the dry season cannot be related to the stage of ontogenetic development but rather to external conditions such as temperature (Mo, 1991; Dávidová et al., 2005). Moreover, morphometric intra-specific 
variability in the haptor was found to be influenced by host species size with significantly larger structures of $K$. limnotrissae and $K$. tanganicanus in bigger host specimens. However, this was not observed in $K$. tanganicanus collected from L. miodon, which confirms previous studies that questioned such correlations in monogeneans (Lakshmi Perera, 1992; Šimková et al., 2001a; Baker et al., 2005). Interestingly, a relation of some morphometric parameters to the geographic origin of both monogenean species was found supporting the potential use of monogeneans as tags for host species stock structure. However, seasonal differences in haptoral measurements of $K$. tanganicanus correspond with the geographical origin of samples and therefore we could not discern these two patterns based on our data set. A fixed pattern in parasite morphometric parameters could possibly indicate differentiation between northern and southern schools of both clupeid species and therefore prove the existence of school structure on a lake wide scale, which hitherto was not detected using fish genetics. However, morphometric intraspecific difference could also result from temporal isolation linked to host recruitment. Nevertheless, the temporal stability of this latitudinal morphometric differentiation has to be confirmed in studies on time series.

Surprisingly, a significantly different length of the accessory piece in $K$. tanganicanus related to host species was documented which could indicate a recent speciation process driven by an incipient reproductive barrier (Kritsky and Boeger, 2002). Although such a process could not be detected using ribosomal DNA markers, faster evolving regions e.g. from mitochondrial DNA or genome-scale data could clarify the situation (Bueno-Silva et al., 2011). Moreover, the copulatory tube length of $K$. tanganicanus seems to be related to seasonality, with a difference between dry and rainy season, suggesting a link between the parasite's age/size and the size of the MCO. However, this pattern has to be tested through more detailed screening on a monthly basis. While no relation to the geographical origin of samples was detected, seasonal variation in copulatory organ development could be possibly correlated with the temperature dependent reproduction and survival of monogeneans (Buchmann, 1988; Šimková et al., 2001b; Tubbs et al., 2005) or the reproduction of host species (Šimková et al., 2005). However, water temperature in Lake Tanganyika is relatively stable with only 1 or $2^{\circ} \mathrm{C}$ annual differences (Coulter and Spigel, 1991; Edmond et al., 1993). Moreover, while S. tanganicae shows a spawning peak prior to the onset of the rainy season, L. miodon seems to have multiple spawning periods throughout the year (Mulimbwa and Shirakihara, 1994; Mulimbwa et al., 2014; Mulimbwa et al., 2014). Therefore, we cannot conclude whether the larger MCO of monogeneans in the rainy season is connected with environmental factors or the spawning season of clupeids. Moreover, the lack of significant influence of any considered factor on the MCO of K. limnotrissae concurs with the multiple spawning periods of L. miodon.

\section{Monogenean host-specificity in the lake's pelagic zone}

While Kapentagyrus limnotrissae is host-specific to Limnothrissa miodon, Kapentagyrus tanganicanus infects both clupeid species in Lake Tanganyika. Although large phenotypic variation in $K$. tanganicanus related to host species was documented, the conspecificity of specimens was confirmed by molecular characterisation. Twenty-five monogenean species have been described from Lake Tanganyika, and most of them are classified as strict (infecting a single host species) or intermediate specialists (parasitizing on two or more congeneric host species). Thus far, Cichlidogyrus casuarinus is the only known intermediate generalist (following the terminology of Mendlová and Šimková, 2014) among Dactylogyridae from Lake Tanganyika, infecting pelagic bathybatine cichlids (Kmentová et al., 2016). Our findings suggest that $K$. tanganicanus is another intermediate generalist. This corroborates previous observations of lower host-specificity in monogeneans in the lake's pelagic zone, in contrast to the species-rich littoral habitat (Kmentová et al., 2016). The phenomenon of reduced host-specificity in the pelagic realm has been suggested to be correlated mainly with the lower host availability in this habitat (Klimpel et al., 2006, 2010; Schoelinck et al., 2012; Kmentová et al., 2016). However, schooling behaviour of clupeids forming large and, potentially, mixed-species groups (Plisnier et al., 2009; Van der Knaap et al., 2014) could be one of the driving mechanisms of parasite host-switch or speciation (Poulin, 1992). This could have resulted in two species of Kapentagyrus infecting clupeids in Lake Tanganyika. Host species hybridisation might explain the more generalist life style of certain monogeneans due to an influence of host genetics on susceptibility to infection, host-specificity, and parasite speciation (Tinsley and Jackson, 1998; Vanhove et al., 2011; Šimková et al., 2013). However, there are no reports of hybridisation among 
Lake Tanganyika's clupeids (Wilson et al., 2008). Sharing of $K$. tanganicanus by both clupeid species, however, might be due to predator-prey transmission of parasites with direct lifecycles. This transmission mechanism was suggested by Strona (2015). Based on this scenario, the presence of $K$. tanganicanus on both clupeid species might be due to direct contact in host predator-prey interactions, as L. miodon is known to predate on S.tanganicae. This hypothesis is supported by previous studies showing strict host-specificity as an ancestral state in the genus Dactylogyrus (Šimková et al., 2006; Šimková and Morand, 2008), with a weak influence of inter-specific competition (Mouillot et al., 2005).

Phylogenetic position and origin of Kapentagyrus in Lake Tanganyika

Results from phylogenetic inference did not reveal a sister-taxon relationship between Kapentagyrus that infects the clupeids of Lake Tanganyika and Cichlidogyrus, indicating independent colonization of Lake Tanganyika. Interestingly, even though many clupeid species have been examined, no dactylogyrid monogenean has ever been reported from marine clupeids (Fig. 5). Although dactylogyrid species of Parancyrocephaloides Yamaguti, 1938 were described from Clupea harengus L., 1758 in Ramappa Lake in India (Kulkarni, 1969), the reported host species and locality are highly questionable as Clupea harengus does not occur in India or the Indian Ocean, see Laxmappa and Rao Bakshi (2016). Therefore, species of Kapentagyrus figure as the only dactylogyrid species ever reported from freshwater clupeids. Despite poor overall resolution, phylogenetic inference of dactylogyrids supported the separate position of Kapentagyrus. Based on this finding, it seems that freshwater sardines, after colonising African inland waters, lost their monogeneans typical for marine representatives and have been afterwards infected by a freshwater lineage. A similar process has been suggested for the monogeneans of cichlids in South America and Africa (Pariselle et al., 2011). However, the origin of this particular dactylogyrid lineage is uncertain as it was placed in a phylogenetically unresolved clade comprising both freshwater and marine representatives (see Fig. 4). A higher coverage in both the number of taxa and loci will be necessary to gain better insights in the biogeographic origins of the monogeneans infecting African freshwater clupeids.

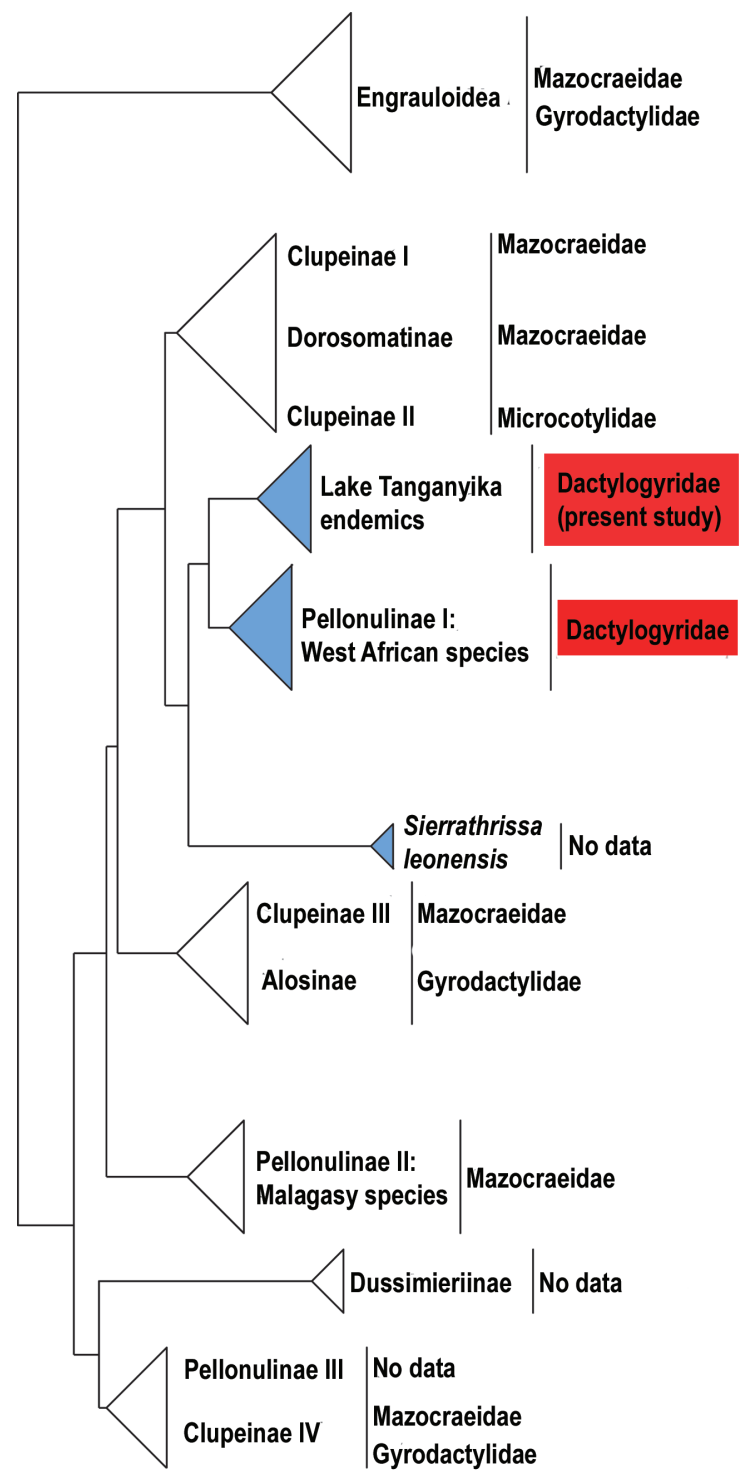

Figure 5. Schematic phylogenetic tree of Clupeidae adapted from Wilson, Teugels and Meyer (2008) indicating the position of continental African freshwater representatives (filled triangles) and the reported presence of monogenean families (dactylogyrids boxed).

\section{Conclusions}

This study provides a description of a new genus, Kapentagyrus supported by morphological and molecular data. Our results re-affirm that host specificity is lower in the pelagic zone of Lake Tanganyika, a conclusion also reached for parasites belonging to Cichlidogyrus (Pariselle et al., 2015; Kmentová et al., 2016). Phylogenetic patterns appear 
to be inconclusive with regard to a colonisation of the originally marine clupeids by dactylogyrids in African freshwaters. However, we note that taxon coverage of other freshwater dactylogyrid species is still very poor and that sequence data for many more species are required to fully understand the obviously highly complex (co-)evolutionary pattern within this monogenean family. Interestingly, phenotypic variability in $K$. tanganicanus was identified related to host species identity with significant differences in haptoral hard parts. Moreover, significant differences in genital parts could possibly indicate the presence of an incipient reproductive barrier (Kritsky and Boeger, 2002). Moreover, the larger copulatory tubes found in $K$. tanganicanus collected in the rainy season could be related to the discontinuous reproduction of their hosts throughout the year. We reported significant intraspecific differences in morphometrics of the haptoral region between specimens collected from the northern, the central and the southern end of Lake Tanganyika. This pattern could indicate a geographic signature in monogenean infection caused by a lack of lake-wide migration in the host species. Further analyses focusing on parasite population genetic structure, phylogeography and demographic history linked with host data are required to reveal the history of this host-parasite system and its potential in recognizing fish population structure. Indeed, parasites, and especially monogeneans, because of their direct life cycle, potentially high substitution rates compared to their host and documented significant phenotypic changes related to geographic origin, might be used to track the history and structure of African clupeid species and fish populations. As clupeids are important fisheries targets in Lake Tanganyika, knowledge on their population structure, health and biology is fundamental to obtain a sustainable management of the species, from which all communities benefit.

\section{Acknowledgements}

The authors would like to thank: Ludmila Raisingerová, Chahrazed Rahmouni, Vercus Lumami Kapepula, Donatien Muzumani Risasi, Joseph Mbirize Ndalozibwa, Simon Kambale Mukeranya, Elias Bilali Mela and VLIR-UOS South Initiative ZEIN2015Z185 for field support. Walter Salzburger, Fabrizia Ronco and Adrian Indermaur are thanked for providing fish samples. We are grateful to Michiel Jorissen for useful discussions about this study. We also thank Tine Huyse, Jos Snoeks, Miguël Parrent (RMCA), Filip Volckaert (KU Leuven) and people in the parasitological group, Masaryk University, Brno and Research Centre of Hydrobiology, Uvira for their hospitality (mission statement number 031/MINRST/CRH-U/2016) and the RMCA for providing access to the collections. Research was supported by the Czech Science Foundation (GBP505/12/G112 - ECIP) as well as by a joint program between the Austrian agency for international mobility and cooperation in education, science and research and the Czech Ministry of Education, Youth and Sports (project number 8J18AT007). A research visit enabling access to the fish collections of RMCA was supported by SYNTHESYS (BE-TAF-5731). The referees are cordially thanked for their useful comments improving this study.

\section{References}

Bagge AM, Poulin R, Valtonen ET. 2004. Fish population size, and not density, as the determining factor of parasite infection: a case study. Parasitology 128: 305-313.

Baker TG, Viricel A, Meraziz L, de Buron I. 2005. Size variation of adult polyopisthocotylid Metamicrocotyla macracantha (Monogenea) in relation to host size. Comparative Parasitology 72: 179-182.

Blasco-Costa I, Míguez-Lozano R, Sarabeev V, Balbuena JA. 2012. Molecular phylogeny of species of Ligophorus (Monogenea: Dactylogyridae) and their affinities within the Dactylogyridae. Parasitology International 61: 619-627.

Brown KJ, Rüber L, Bills R, Day JJ. 2010. Mastacembelid eels support Lake Tanganyika as an evolutionary hotspot of diversification. BMC Evolutionary Biology 10: 188.

Bueno-Silva M, Boeger WA, Pie MR. 2011. Choice matters: Incipient speciation in Gyrodactylus corydori (Monogenoidea: Gyrodactylidae). International Journal for Parasitology 41: 657-667.

Buchmann K. 1988. Temperature-dependent reproduction and survival of Pseudodactylogyrus bini (Monogenea) on the European eel (Anguilla anguilla). Parasitology Research 75: $162-164$.

Bychowsky BE, Nagibina LF. 1970. Contribution to the revision of the genus Ancyrocephalus Creplin, 1839 (Dactylogyrida, Ancyrocephalinae). Parazitologiya 3: 193-200.

Capella-Gutiérrez S, Silla-Martínez JM, Gabaldón T. 2009. trimAl: a tool for automated alignment trimming in largescale phylogenetic analyses. Bioinformatics Application Note 25: 1972-1973.

Chapman DW, van Well P. 1978. Growth and mortality of Stolothrissa tanganicae. Transactions of the American Fisheries Society 107: 26-35.

Coenen EJ, Hanek G, Kotilainen P. 1993. Shoreline classification of Lake Tanganyika based on the results of an aerial frame survey (29.09-03.10.1992). FAO/FINNIDA Research for the Management of the Fisheries on Lake Tanganyika: 11.

Cohen AS, Lezzar KE, Cole J, Dettman D, Ellis GS, Gonneea ME, Plisnier PD, Langenberg V, Blaauw M, Zilifi D. 2006. Late Holocene linkages between decade-century scale climate variability and productivity at Lake Tanganyika, Africa. Journal of Paleolimnology 36: 189-209.

Cohen AS, Soreghan MJ, Scholz CA. 1993. Estimating the age of formation of lakes: An example from Lake Tanganyika, East African Rift system. Geology 21: 511.

Coulter GW. 1970. Population changes within a group of fish species in Lake Tanganyika following their exploitation. 
Journal of Fish Biology 2: 329-353.

Coulter GW. 1976. The biology of Lates species (Nile perch) in Lake Tanganyika, and the status of the pelagic fishery for Lates species and Luciolates stappersii (Blgr.). Journal of Fish Biology 9: 235-259.

Coulter GW. 1991a. Introduction. In: Coulter GW, ed. Lake Tanganyika and its life. London Oxford \& New York: Natural History Museum Publications \& Oxford University Press, 1-6.

Coulter GW. 1991b. Composition of the flora and fauna. In: Coulter GW, ed. Lake Tanganyika and its life. London Oxford \& New York: Natural History Musem Publications \& Oxford University Press, 200-274.

Coulter GW, Spigel RH. 1991. Hydrodynamics. In: Coulter GW, ed. Lake Tanganyika and its life. London Oxford \& New York: Natural History Museum Publications \& Oxford University Press, 49-75.

Criscione CD, Cooper B, Blouin MS. 2006. Parasite genotypes identify source populations of migratory fish more accurately than fish genotypes. Ecology 87: 823-828.

Danley PD, Husemann M, Ding B, Dipietro LM, Beverly EJ, Peppe DJ. 2012. The impact of the geologic history and paleoclimate on the diversification of East African cichlids. International Journal of Evolutionary Biology: 574851.

Dávidová M, Jarkovský J, Matějusová I, Gelnar M. 2005. Seasonal occurrence and metrical variability of Gyrodactylus rhodei Žitňan 1964 (Monogenea, Gyrodactylidae). Parasitology Research 95: 398-405.

Day JJ, Wilkinson M. 2006. On the origin of the Synodontis catfish species flock from Lake Tanganyika. Biology Letters 2: 548-552.

Dogiel VA, Bogolepova II. 1957. Parasitic fauna of Lake Baikal fishes. Trudy Baikalskoi Limnologicheskoi Stancii Akademiya Nauk SSR.

Eccles DH. 1992. Field guide to the freshwater fishes of Tanzania. FAO Species Identification Sheets for Fishery Purposes.

Edgar RC. 2004. MUSCLE: Multiple sequence alignment with high accuracy and high throughput. Nucleic acids research 32: 1792-1797.

Edmond JM, Stallard RF, Craig H, Craig V, Weiss RF, Coulter GW. 1993. Nutrient chemistry of the water column of Lake Tanganyika. Limnology and Oceanography 38: 725-738.

Ergens R, Lom J. 1970. Causative agents of fish diseases. Prague: Academia.

Erpenbeck D, Weier T, de Voogd NJ, Wörheide G, Sutcliffe P, Todd JA, Michel E. 2011. Insights into the evolution of freshwater sponges (Porifera: Demospongiae: Spongillina): Barcoding and phylogenetic data from Lake Tanganyika endemics indicate multiple invasions and unsettle existing taxonomy. Molecular Phylogenetics and Evolution 61: 231236.

Eschmeyer WN, Fong JD. 2017. Catalog of Fishes. Species by family/subfamily.

Fankoua SO, Bitja Nyom AR, Bahanak DND, Bilong Bilong CF, Pariselle A. 2017. Influence of preservative and mounting media on the size and shape of monogenean sclerites. Parasitology Research 116: 2277-2281.

Filzmoser P, Gschwandtner M. 2017. mvoutlier: Multivariate outlier detection based on robust methods. : https://CRAN.Rproject.org $/$ package $=$ mvoutlier.
Fryer G. 1991. Comparative aspects of adaptive radiation and speciation in Lake Baikal and the great rift lakes of Africa. Hydrobiologia 211: 137-146.

García-Varela M, Sereno-Uribe AL, Pinacho-Pinacho CD, Domínguez-Domínguez O, Pérez-Ponce de León G. 2016. Molecular and morphological characterization of Austrodiplostomum ostrowskiae Dronen, 2009 (Digenea: Diplostomatidae), a parasite of cormorants in the Americas. Journal of Helminthology 90: 174-185.

Gérard C, Hervé M, Réveillac E, Acou A. 2016. Spatial distribution and impact of the gill-parasitic Mazocraes alosae (Monogenea Polyopisthocotylea) on Alosa alosa and A. fallax (Actinopterygii, Clupeidae). Hydrobiologia 763: 371-379.

Glaubrecht M. 2008. Adaptive radiation of thalassoid gastropods in Lake Tanganyika, East Africa: morphology and systematization of a paludomid species flock in an ancient lake. Zoosystematics and Evolution 84: 71-122.

Gourène G, Teugels G. 1993. Position taxinomique de Limnothrissa strappersii, un clupéidé lacustre d'Afrique centrale. Ichthyological Exploration of Freshwaters 4: 367374.

Grégoir AF, Hablützel PI, Vanhove MPM, Pariselle A, Bamps J, Volckaert FAM, Raeymaekers JAM. 2015. A link between host dispersal and parasite diversity in two sympatric cichlids of Lake Tanganyika. Freshwater Biology 60: 323-335.

Hablützel PI, Grégoir AF, Vanhove MPM, Volckaert FAM, Raeymaekers JAM. 2016. Weak link between dispersal and parasite community differentiation or immunogenetic divergence in two sympatric cichlid fishes. Molecular Ecology 25: 5451-5466.

Hablützel PI, Vanhove MPM, Deschepper P, Grégoir AF, Anna K. 2017. Parasite escape through trophic specialization in a species flock. Journal of Evolutionary Biology 30: 14371445.

Hablützel PI, Vanhove MPM, Deschepper P, Grégoir AF, Roose AK, Volckaert FAM, Raeymaekers JAM. 2017. Parasite escape through trophic specialization in a species flock. Journal of Evolutionary Biology 30: 1437-1445.

Hassouna N, Michot B, Bachellerie JP, Narbonne D. 1984. The complete nucleotide sequence of mouse $28 \mathrm{~S}$ rRNA gene. Implications for the process of size increase of the large subunit rRNA in higher eukaryotes. Nucleic Acids Research 12: 3563-3583.

Hauser L, Carvalho GR, Pitcher TJ. 1995. Morphological and genetic differentiation of the African clupeid Limnothrissa miodon 34 years after its introduction to Lake Kivu. Journal of Fish Biology 47: 127-144.

Hauser L, Carvalho GR, Pitcher TJ. 1998. Genetic population structure in the Lake Tanganyika sardine Limnothrissa miodon. Journal of Fish Biology 53: 413-429.

Hecky RE. 1991. The pelagic ecosystem. In: Coulter GW, ed. Lake Tanganyika and its life. London Oxford \& New York: Natural History Musem \& Oxford University Press, 91-110.

Hecky RE, Fee EJ, Kling HJ, Rudd JWM. 1981. Relationship between primary production and fish production in Lake Tanganyika. Transactions of the American Fisheries Society 110: 336-345

Huyse T, Malmberg G. 2004. Molecular and morphological comparisons between Gyrodactylus ostendicus n. sp. (Monogenea: Gyrodactylidae) on Pomatoschistus microps 
(Krøyer) and $G$. harengi Malmberg, 1957 on Clupea harengus membras. Systematic Parasitology 58: 105-113.

International Commission on Zoological Nomenclature. 2012. Amendment of articles 8,9,10,21 and 78 of the International Code of Zoological Nomenclature to expand and refine methods of publication. Zootaxa 3450: 1-7.

Jombart T. 2008. Adegenet: A R package for the multivariate analysis of genetic markers. Bioinformatics 24: 1403-1405.

Justine JL, Beveridge I, Boxshall GA, Bray RA, Miller TL, Moravec F, Trilles JP, Whittington ID. 2012. An annotated list of fish parasites (Isopoda, Copepoda, Monogenea, Digenea, Cestoda, Nematoda) collected from Snappers and Bream (Lutjanidae, Nemipteridae, Caesionidae) in New Caledonia confirms high parasite biodiversity on coral reef fish. Aquatic Biosystems 8: 22.

Kaci-Chaouch T, Verneau O, Desdevises Y. 2008. Host specificity is linked to intraspecific variability in the genus Lamellodiscus (Monogenea). Parasitology 135: 607-616.

Kearn GC. 1967. Experiments on host-finding and hostspecificity in the monogenean skin parasite Entobdella soleae. Parasitology 57: 585-605.

Kearn GC. 1968. The development of the adhesive organs of some diplectanid, tetraonchid and dactylogyrid gill parasites (Monogenea). Parasitology 58: 149-163.

Klimpel S, Busch MW, Sutton T, Palm HW. 2010. Meso- and bathy-pelagic fish parasites at the Mid-Atlantic Ridge (MAR): Low host specificity and restricted parasite diversity. Deep-Sea Research Part I: Oceanographic Research Papers 57: 596-603.

Klimpel S, Palm HW, Busch MW, Kellermanns E, Rückert S. 2006. Fish parasites in the Arctic deep-sea: Poor diversity in pelagic fish species vs. heavy parasite load in a demersal fish. Deep-Sea Research Part I: Oceanographic Research Papers 53: 1167-1181.

Kmentová N, Gelnar M, Mendlová M, Van Steenberge M, KoblmüllerS, Vanhove MPM. 2016. Reduced host-specificity in a parasite infecting non-littoral Lake Tanganyika cichlids evidenced by intraspecific morphological and genetic diversity. Scientific Reports 6: 39605.

Koblmüller S, Sefc KM, Sturmbauer C. 2008. The Lake Tanganyika cichlid species assemblage: Recent advances in molecular phylogenetics. Hydrobiologia 615: 5-20.

Koblmüller S, Sturmbauer C, Verheyen E, Meyer A, Salzburger W. 2006. Mitochondrial phylogeny and phylogeography of East African squeaker catfishes (Siluriformes: Synodontis). BMC Evolutionary Biology 6: 49.

Kritsky DC, Boeger WA. 2002. Neotropical Monogenoidea: 41. New and previously described species of Dactylogyridae (Platyhelminthes) from the gills of marine and freshwater perciform fishes (Teleostei) with proposal of a new genus and a hypothesis on phylogeny. Zoosystema 24: 7-40.

Kulkarni T. 1969. Studies on the monogenetic trematodes of fishes found in Hyderabad, Andhra Pradesh (India) - Part II. Rivista di Parassitologia 30: 263-282.

Kumar S, Stecher G, Tamura K, Gerken J, Pruesse E, Quast C, Schweer T, Peplies J, Ludwig W, Glockner F. 2016. MEGA7: Molecular evolutionary genetics analysis Version 7.0 for bigger datasets. Molecular Biology and Evolution 33: 1870-1874.

Kuris AM, Hechinger RF, Shaw JC, Whitney KL, AguirreMacedo L, Boch CA, Dobson AP, Dunham EJ, Fredensborg
BL, Huspeni TC, Lorda J, Mababa L, Mancini FT, Mora AB, Pickering M, Talhouk NL, Torchin ME, Lafferty KD. 2008. Ecosystem energetic implications of parasite and free-living biomass in three estuaries. Nature 454: 515-518.

Lakshmi Perera KM. 1992. The effect of host size on large hamuli length of Kuhnia scombri (Monogenea: Polyopisthocotylea) from Eden, New South Wales, Australia. International Journal for Parasitology 22: 123-124.

Langenberg VT, Mwape LM, Tshibangu K, Tumba JM, Koelmans AA, Roijackers R, Salonen K, Sarvala J, Mölsä H. 2002. Comparison of thermal stratification, light attenuation, and chlorophyll- a dynamics between the ends of Lake Tanganyika. Aquatic Ecosystem Health \& Management 5: 255-265.

Lavoué S, Konstantinidis P, Chen WJ. 2014. Progress in clupeiform systematics. In: Ganias K, ed. Biology and ecology of sardines and anchovies. CRC Press, 3-42.

Laxmappa B, Rao Bakshi R. 2016. A checklist of fishes of Telangana State, India. International Journal of Fisheries and Aquatic Studies 4: 35-42.

MacKenzie K. 1983. Parasites as biological tags in fish population studies. Advances in Applied Biology 7: 251-331.

Maddison WP, Maddison DR. 2017. Mesquite: a modular system for evolutionary analysis. Version $3.2 \mathrm{http} / / /$ mesquiteproject. org.

Mannini P, Aro E, Katonda KI, Kassaka B, Mambona C, Milindi G, Paffen P, Verburg P. 1996. Pelagic fish stocks of Lake Tanganyika: biology and exploitation. FAO/FINNIDA research for the management of the fisheries of Lake Tanganyika. GCP/RAF/271/FIN-TD/53 (En): 60 .

Marijnissen SAE, Michel E, Daniels SR, Erpenbeck D, Menken SBJ, Schram FR. 2006. Molecular evidence for recent divergence of Lake Tanganyika endemic crabs (Decapoda: Platythelphusidae). Molecular Phylogenetics and Evolution 40: 628-634.

Marshall BE. 1993. Biology of the African clupeid Limnothrissa miodon with reference to its small size in artificial lakes. Reviews in Fish Biology and Fisheries 3: 17-38.

Meixner MJ, Lüter C, Eckert C, Itskovich V, Janussen D, von Rintelen T, Bohne AV, Meixner JM, Hess WR. 2007. Phylogenetic analysis of freshwater sponges provide evidence for endemism and radiation in ancient lakes. Molecular Phylogenetics and Evolution 45: 875-886.

Mendlová M, Šimková A. 2014. Evolution of host specificity in monogeneans parasitizing African cichlid fish. Parasites \& Vectors 7: 69.

Mendoza-Garfias B, Pérez-Ponce de Léon G. 1998. Microcotílidos (Monogenea:Microcotylidae) parasitos de peces marinos de la Bahía de Chamela, Jalisco, México. Anales del Instituto de Biología. Serie Zoología 69: 139-153.

Messu Mandeng FD, Bilong Bilong CF, Pariselle A, Vanhove MPM, Bitja Nyom AR, Agnèse JF. 2015. A phylogeny of Cichlidogyrus spp. (Monogenea, Dactylogyridea) clarifies a host-switch between fish families and reveals an adaptive component to attachment organ morphology of this parasite genus. Parasites \& Vectors 8: 582.

Michel E. 1995. Evolutionary diversification of rift lake gastropods: Morphology, anatomy, genetics and biogeography of Lavigeria (Mollusca: Thiaridae) in Lake Tanganyika. Unpublished thesis, The University of Arizona.

Milne I, Wright F, Rowe G, Marshall DF, Husmeier D, McGuire 
G. 2004. TOPALi: software for automatic identification of recombinant sequences within DNA multiple alignments. Bioinformatics 20: 1806-1807.

Mladineo I, Šegvić-Bubić T, Stanić R, Desdevises Y. 2013. Morphological plasticity and phylogeny in a monogenean parasite transferring between wild and reared fish populations. PLOS ONE 8: e62011.

Mo TA. 1991. Variations of opisthaptoral hard parts of Gyrodactylus salaris Malmberg, 1957 (Monogenea: Gyrodactylidae) on parr of Atlantic Salmon Salmo salar L. in laboratory experiments. Systematic Parasitology 20: 11-19.

Moore JES. 1897. The fresh-water fauna of Lake Tanganyika. Nature 56: 198-200.

Mouillot D, Šimková A, Morand S, Poulin R. 2005. Parasite species coexistence and limiting similarity: a multiscale look at phylogenetic, functional and reproductive distances. Oecologia 146: 269-278.

Mulimbwa N, Raeymaekers JAM, Sarvala J. 2014. Seasonal changes in the pelagic catch of two clupeid zooplanktivores in relation to the abundance of copepod zooplankton in the northern end of Lake Tanganyika. Aquatic Ecosystem Health and Management 17: 25-33.

Mulimbwa N, Sarvala J, Raeymaekers JAM. 2014. Reproductive activities of two zooplanktivorous clupeid fish in relation to the seasonal abundance of copepod prey in the northern end of Lake Tanganyika. Belgian Journal of Zoology 144: 77-92.

Mulimbwa N, Shirakihara K. 1994. Growth, recruitment and reproduction of sardines (Stolothrissa tanganicae and Limnothrissa miodon) in northwestern Lake Tanganyika. Tropics 4: 57-67.

Muschick M, Nosil P, Roesti M, Dittmann MT, Harmon L, Salzburger W. 2014. Testing the stages model in the adaptive radiation of cichlid fishes in East African Lake Tanganyika. Proceedings of the Royal Society B: Biological Sciences 281: 20140605.

Nelson JS. 2006. Fishes of the world. 4th ed. New Jersey, USA: John Wiley \& Sons.

Oliva ME, Gonzalez MT. 2004. Metazoan parasites of Sebastes capensis from two localities in northern Chile as tools for stock identification. Journal of Fish Biology 64: 170-175.

Paperna I. 1973. New species of Monogenea (Vermes) from African freshwater fish. A preliminary report. Revue de Zoologie et de Botanique Africaines 87: 505-518.

Paperna I. 1979. Monogenea of inland water fish in Africa. Royal Museum for Central Africa.

Pariselle A, Boeger WA, Snoeks J, Bilong Bilong CF, Morand S, Vanhove MPM. 2011. The monogenean parasite fauna of cichlids: a potential tool for host biogeography. International Journal of Evolutionary Biology 2011: 471480.

Pariselle A, Muterezi Bukinga F, Van Steenberge M, Vanhove MPM. 2015. Ancyrocephalidae (Monogenea) of Lake Tanganyika: IV: Cichlidogyrus parasitizing species of Bathybatini (Teleostei, Cichlidae): reduced host-specificity in the deep water realm? Hydrobiologia 748: 99-119.

Peart CR, Bills R, Wilkinson M, Day JJ. 2014. Nocturnal claroteine catfishes reveal dual colonisation but a single radiation in Lake Tanganyika. Molecular Phylogenetics and Evolution 73: 119-128.

Plisnier PD, Mgana H, Kimirei I, Chande A, Makasa L, Chimanga J, Zulu F, Cocquyt C, Horion S, Bergamino N, Naithani J, Deleersnijder E, André L, Descy JP, Cornet Y.
2009. Limnological variability and pelagic fish abundance (Stolothrissa tanganicae and Lates stappersii) in Lake Tanganyika. Hydrobiologia 625: 117-134.

Poll M, Gosse JP. 1995. Genera des poissons d'eau douce de l'Afrique. Mémoire de la Classe des Sciences. Académie royale de Belgique.

Poulin R. 1992. Determinants of host-specificity in parasites of freshwater fishes. International Journal for Parasitology 22: $753-758$.

Poulin R. 2000. Variation in the intraspecific relationship between fish length and intensity of parasitic infection: biological and statistical causes. Journal of Fish Biology 56: 123-137.

Poulin R. 2007. Evolutionary ecology of parasites. 2nd ed. (R Poulin, Ed.). Princeton, New Jersey: Princeton University Press.

Poulin R, Kamiya T. 2015. Parasites as biological tags of fish stocks: a meta-analysis of their discriminatory power. Parasitology 142: 145-155.

Poulin R, Morand S. 2004. Parasite biodiversity. Washington: Smithsonian Books.

Preston DL, Orlofske SA, Lambden JP, Johnson PTJ. 2013. Biomass and productivity of trematode parasites in pond ecosystems (D Tompkins, Ed.). Journal of Animal Ecology 82: 509-517.

Pugachev ON, Gerasev PI, Gussev A V., Ergens R, Khotenowsky I. 2009. Guide to Monogenoidea of freshwater fish of Palaeartic and Amur regions (P Galli, ON Pugachev, and D Kritsky, Eds.). Milan: Ledizione-LediPublishing.

R Core Team. 2013. R: A language and environment for statistical computing. Vienna, Austria: R Foundation for Statistical Computing.

$\mathrm{R}$ development core team. 2011. R: A language and environment for statistical computing. $R$ Foundation for Statistical Computing. Vienna, Austria: the R Foundation for Statistical Computing.

Raeymaekers JAM, Hablützel PI, Grégoir AF, Bamps J, Roose AK, Vanhove MPM, Van Steenberge M, Pariselle A, Huyse T, Snoeks J, Volckaert FAM. 2013. Contrasting parasite communities among allopatric colour morphs of the Lake Tanganyika cichlid Tropheus. BMC Evolutionary Biology 13: 41.

Rambaut A, Suchard MA, Drummond AJ. 2014. Tracer v1.6, Available from http://beast.bio.ed.ac.uk/Tracer.

Rodríguez F, Oliver JL, Marín A, Medina JR. 1990. The general stochastic model of nucleotide substitution. Journal of Theoretical Biology 142: 485-501.

Rohde K. 1980. Diversity gradients of marine Monogenea in the Atlantic and Pacific Oceans. Experientia 36: 1368-1369.

Rohde K. 1988. Gill Monogenea of deep water and surface fish in southeastern Australia. Hydrobiologia 160: 271-283.

Rohde K, Hayward C, Heap M. 1995. Aspects of the ecology of metazoan ectoparasites of marine fishes. International Journal for Parasitology 25: 945-970.

Ronquist F, Teslenko M, van der Mark P, Ayres DL, Darling A, Hohna S, Larget B, Liu L, Suchard MA, Huelsenbeck JP. 2012. MrBayes 3.2: Efficient Bayesian phylogenetic inference and model choice across a large model space. Systematic Biology 61: 539-542.

Řehulková E, Mendlová M, Šimková A. 2013. Two new species of Cichlidogyrus (Monogenea: Dactylogyridae) parasitizing 
the gills of African cichlid fishes (Perciformes) from Senegal: Morphometric and molecular characterization. Parasitology Research 112: 1399-1410.

Sanchez-Garcia N, Raga JA, Montero FE. 2015. Morphological and attachment changes of Lamellodiscus theroni (Monogenea: Diplectanidae) during its post-larval development on fish. Folia Parasitologica 62: 026.

Santos ME, Salzburger W. 2012. Evolution. How cichlids diversify. Science (New York, N.Y.) 338: 619-21.

Sefc K, Mattersdorfe K, Ziegelbecker A, Neuhüttler N, Steiner O, Goessler W, Koblmüller S. 2017. Shifting barriers and phenotypic diversification by hybridization. Ecology Letters 20: 651-662.

Schoelinck C, Cruaud C, Justine JL. 2012. Are all species of Pseudorhabdosynochus strictly host specific? - A molecular study. Parasitology International 61: 356-359.

Sigura A, Justine J-L. 2008. Monogeneans of the speckled blue grouper, Epinephelus cyanopodus (Perciformes, Serranidae), from off New Caledonia, with a description of four new species of Pseudorhabdosynochus and one new species of Laticola (Monogenea: Diplectanidae), and evidence of monogenean faunal changes according to the size of fish. Zootaxa 1695: 1-44.

Sinnappah ND, Lim LHS, Rohde K, Tinsley R, Combes C, Verneau O. 2001. A paedomorphic parasite associated with a neotenic amphibian host: phylogenetic evidence suggests a revised systematic position for sphyranuridae within anuran and turtle polystomatoineans. Molecular Phylogenetics and Evolution 18: 189-201.

Stamatakis A. 2014. RAxML version 8: A tool for phylogenetic analysis and post-analysis of large phylogenies. Bioinformatics 30: 1312-1313.

Strona G. 2015. The underrated importance of predation in transmission ecology of direct lifecycle parasites. Oikos 124: $685-690$.

Sturmbauer C, Baric S, Salzburger W, Rüber L, Verheyen E. 2001. Lake level fluctuations synchronize genetic divergences of cichlid fishes in African lakes. Molecular Biology and Evolution 18: 144-154.

Šimková A, Dávidová M, Papoušek I, Vetešník L. 2013. Does interspecies hybridization affect the host specificity of parasites in cyprinid fish? Parasites \& Vectors 6: 95.

Šimková A, Desdevise Y, Gelnar M, Morand S. 2001a. Morphometric correlates of host specificity in Dactylogyrus species (Monogenea) parasites of European Cyprinid fish. Parasitology 123: 169-177.

Šimková A, Jarkovský J, Koubková B, Baruš V, Prokeš M. 2005. Associations between fish reproductive cycle and the dynamics of metazoan parasite infection. Parasitology Research 95: 65-72.

Šimková A, Morand S. 2008. Co-evolutionary patterns in congeneric monogeneans: a review of Dactylogyrus species and their cyprinid hosts. Journal of Fish Biology 73: 22102227.

Šimková A, Plaisance L, Matějusová I, Morand S, Verneau O. 2003. Phylogenetic relationships of the Dactylogyridae Bychowsky, 1933 (Monogenea: Dactylogyridea): The need for the systematic revision of the Ancyrocephalinae Bychowsky, 1937. Systematic Parasitology 54: 1-11.

Šimková A, Sasal P, Kadlec D, Gelnar M. 2001b. Water temperature influencing dactylogyrid species communities in roach, Rutilus rutilus, in the Czech Republic. Journal of Helminthology 75: 373-383.

Šimková A, Verneau O, Gelnar M, Morand S. 2006. Specificity and specialization of congeneric monogeneans parasitizing cyprinid fish. Evolution 60: 1023-1037.

Tinsley RC, Jackson JA. 1998. Correlation of parasite speciation and specificity with host evolutionary relationships. International Journal for Parasitology 28: 1573-1582.

Tubbs LA, Poortenaar CW, Sewell MA, Diggles BK. 2005. Effects of temperature on fecundity in vitro, egg hatching and reproductive development of Benedenia seriolae and Zeuxapta seriolae (Monogenea) parasitic on yellowtail kingfish Seriola lalandi. International Journal for Parasitology 35: 315-327.

Turner GF. 2007. Adaptive radiation of cichlid fish. Current Biology 17: 827-831.

Van der Knaap M, Katonda KI, De Graaf GJ. 2014. Lake Tanganyika fisheries frame survey analysis: Assessment of the options for management of the fisheries of Lake Tanganyika. Aquatic Ecosystem Health \& Management 17: 4-13.

Vanhove MPM, Pariselle A, Van Steenberge M, Raeymaekers JAM, Hablützel PI, Gillardin C, Hellemans B, Breman FC, Koblmüller S, Sturmbauer C, Snoeks J, Volckaert FAM, Huyse T. 2015. Hidden biodiversity in an ancient lake: phylogenetic congruence between Lake Tanganyika tropheine cichlids and their monogenean flatworm parasites. Scientific Reports 5: 13669.

Vanhove MPM, Volckaert FAM, Pariselle A. 2011. Ancyrocephalidae (Monogenea) of Lake Tanganyika: I: Four new species of Cichlidogyrus from Ophthalmotilapia ventralis (Teleostei: Cichlidae), the first record of this parasite family in the basin. Zoologia (Curitiba) 28: 253263.

Williams HH, MacKenzie K, McCarthy AM. 1992. Parasites as biological indicators of the population biology, migrations, diet, and phylogenetics of fish. Reviews in Fish Biology and Fisheries 2: 144-176.

Wilson AB, Teugels GG, Meyer A. 2008. Marine incursion: the freshwater herring of Lake Tanganyika are the product of a marine invasion into west Africa. PLOS ONE 3: e1979.

Ziętara MS, Lumme J. 2002. Speciation by host switch and adaptive radiation in a fish parasite genus Gyrodactylus (Monogenea, Gyrodactylidae). Evolution 56: 2445-2458.

Received: 8 December 2017

Revised and accepted: 14 May 2018

Published online: 12 September 2018

Editor: R. Sluys

\section{Online supplementary information}

S1. List of dactylogyrid species obtained from GenBank with their accession numbers for the rDNA region retrieved and their host species. 


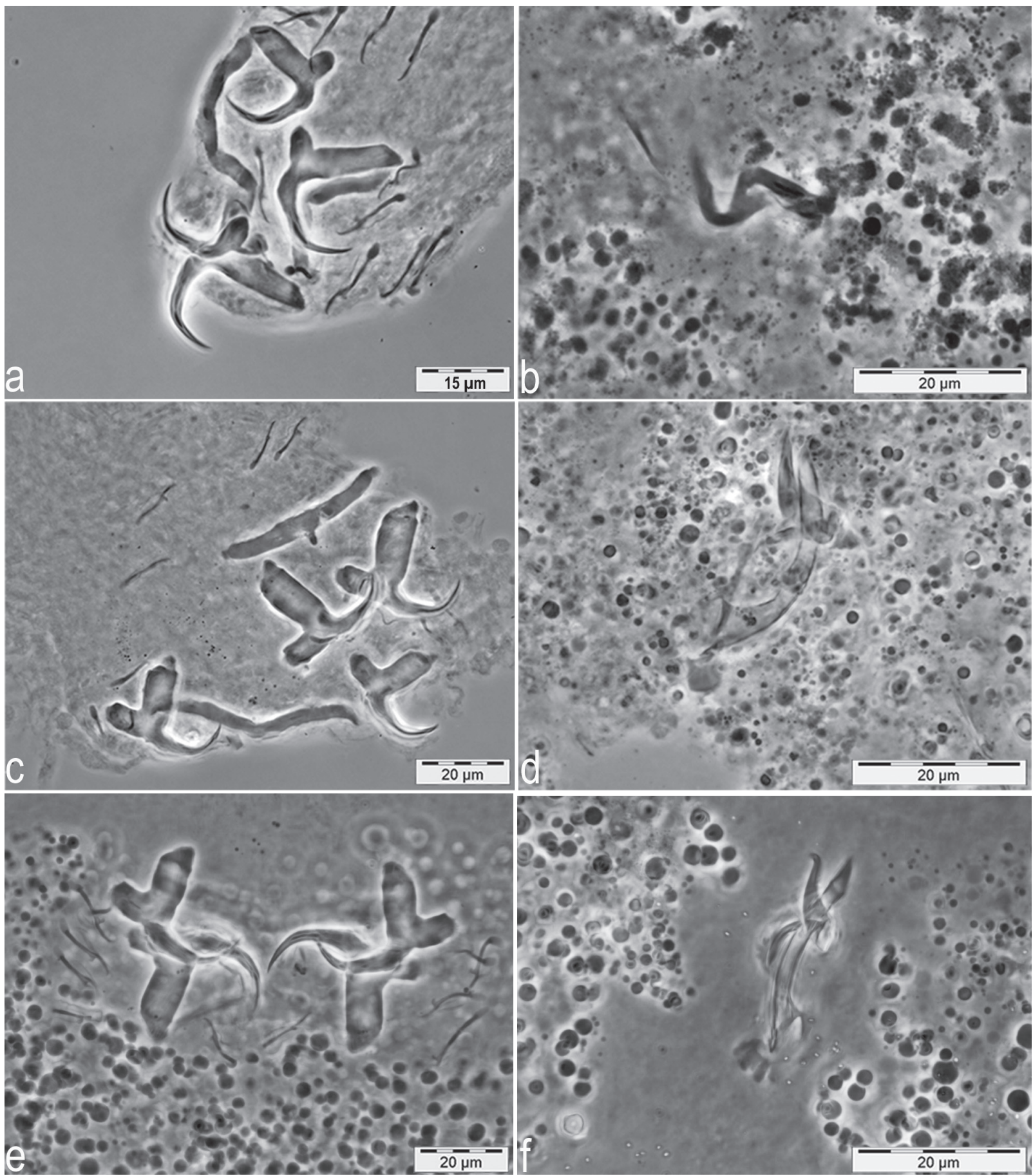

Figure 6. Haptoral and male genital sclerotised structures of monogenean species collected in this study (Hoyer's medium, phasecontrast photomicrographs). a) Opisthaptor of Kapentagyrus limnotrissae b) Male copulatory organ of K. limnotrissae c) Opisthaptor of $K$. tanganicanus from L. miodon d) Male copulatory organ of $K$. tanganicanus from L. miodon e) Opisthaptor of $K$. tanganicanus from $S$. tanganicae f) Male copulatory organ of $K$. tanganicanus from S. tanganicae. 


\section{Appendix}

In this section, Kapentagyrus Kmentová, Gelnar and Vanhove, gen. nov. is described with Ancyrocephalus limnotrissae as type species for which re-description and new records are provided. Moreover, Kapentagyrus tanganicanus Kmentová, Gelnar and Vanhove, sp. nov. is described as new species displaying two different haptoral morphologies. The type series of the two species are deposited in the Royal Museum for Central Africa (RMCA); the Iziko South African Museum (SAMC), Cape Town, Republic of South Africa; the Finnish Museum of Natural History (MZH), Helsinki, Finland; the Muséum national d'Histoire naturelle $(\mathrm{MNHN})$, Paris, France; and in the Natural History Museum (NHMUK), London, United Kingdom. Note that the authors of the new taxa are different from the authors of this paper; see article 50.1, recommendation $50 \mathrm{~A}$ and $51 \mathrm{E}$ of the International Code of Zoological 3 Nomenclature (ICZN, 1999: Article 50.1, recommendation 50A and 51E).

\section{Taxonomic account}

Family: Dactylogyridae Yamaguti, 1963

Kapentagyrus Kmentová, Gelnar and Vanhove, gen. nov.

Type species: Ancyrocephalus limnotrissae Paperna, 1973 (original designation)

Other species. Kapentagyrus tanganicanus, Kapentagyrus pellonulae comb. nov. for Ancyrocephalus pellonulae Paperna, 1969

Type-host. Limnothrissa miodon (Boulenger, 1906) (Clupeidae).

Type-locality. Lake Tanganyika, Tanzania

Etymology. Since the species assigned to this new genus are known only from clupeids, the representatives of which are known as "kapenta" locally around part of Lake Tanganyika's shoreline, the first part of the genus name refers to a vernacular name of the host. The second part refers to the circular pattern of hooks or extensions and is frequently used in other monogenean genera. Gender: masculine.

Diagnosis. Kapentagyrus is a new genus of the family Dactylogyridae (Monogenea). Main diagnostic characters include the combination of (1) welldeveloped anchor roots together with (2) the presence of two V-shaped transversal haptoral bars without auricles.

Description. [Based on 106 specimens; Fig. 6, see measurements in Table 3.]. Kapentagyrus, and its type species $K$. limnotrissae are characterised by two pairs of anchors with well-incised roots and a regularly curved point. Ventral anchors slightly larger than dorsal anchors with more developed inner roots. Dorsal and ventral bar wide, V-shaped with constant width. Dorsal bar larger than ventral bar. Seven pairs of hooks, pairs 1 and 5 with same size, shorter than pairs 2, 3, 4, 6 and 7. Male copulatory organ formed by straight copulatory tube; accessory piece coiled once around the tube. No sclerotized vagina observed. Based on Paperna $(1973,1979)$, the internal anatomy of the type species comprises a single ovary, dextral vagina, one prostatic gland and seminal vesicle, post-ovarian testis, intestinal limbs that are not united, and a vas deferens which does not loop around the intestinal limbs. Examination of internal anatomy was not included in this study.

Discussion. The uniqueness of the proposed new genus lies in the regularly shaped anchors and bars with almost no difference in size or shape between ventral and dorsal side, the same size of the first and fifth pair of the marginal hooks and the S-shaped accessory piece twisted around the copulatory tube. The species, originally described as Ancyrocephalus limnotrissae, was chosen as type species because of the available genetic information and the original description containing internal soft parts (Paperna, 1979). Importantly, as mentioned in the original description of Ancyrocephalus limnotrissae, it differs from Ancyrocephalus sensu stricto Creplin, 1839 by the developed roots of both the dorsal and the ventral anchor, the longer anchor shafts, the different shape of the haptoral transversal bars, the non-triangular shape of the accessory piece of the $\mathrm{MCO}$ and by the presence of just one prostatic gland (Bychowsky and Nagibina, 1970; Paperna, 1979). A morphologically similar genus is Cichlidogyrus Paperna, 1960, which infects Levantine and African cichlids (including those in Lake Tanganyika), but which differs from Kapentagyrus by the presence of auricles in the dorsal bar and in often having a more asymmetrical dorsal anchor compared to the ventral one. Other monogenean genera known from African freshwaters with two pairs of anchors and similar dorsal and ventral bars are Annulotrema Paperna and Thurston, 1969 and Afrocleidodiscus Paperna, 1969. In both cases, there are differences either in the shape of the bars or in the more developed anchor roots of Kapentagyrus. Moreover, representatives of the two aforementioned genera were described from host species belonging to the fish families Alestidae and Distichodontidae, respectively. European parasites considered to belong to the Ancyrocephalidae sensu 


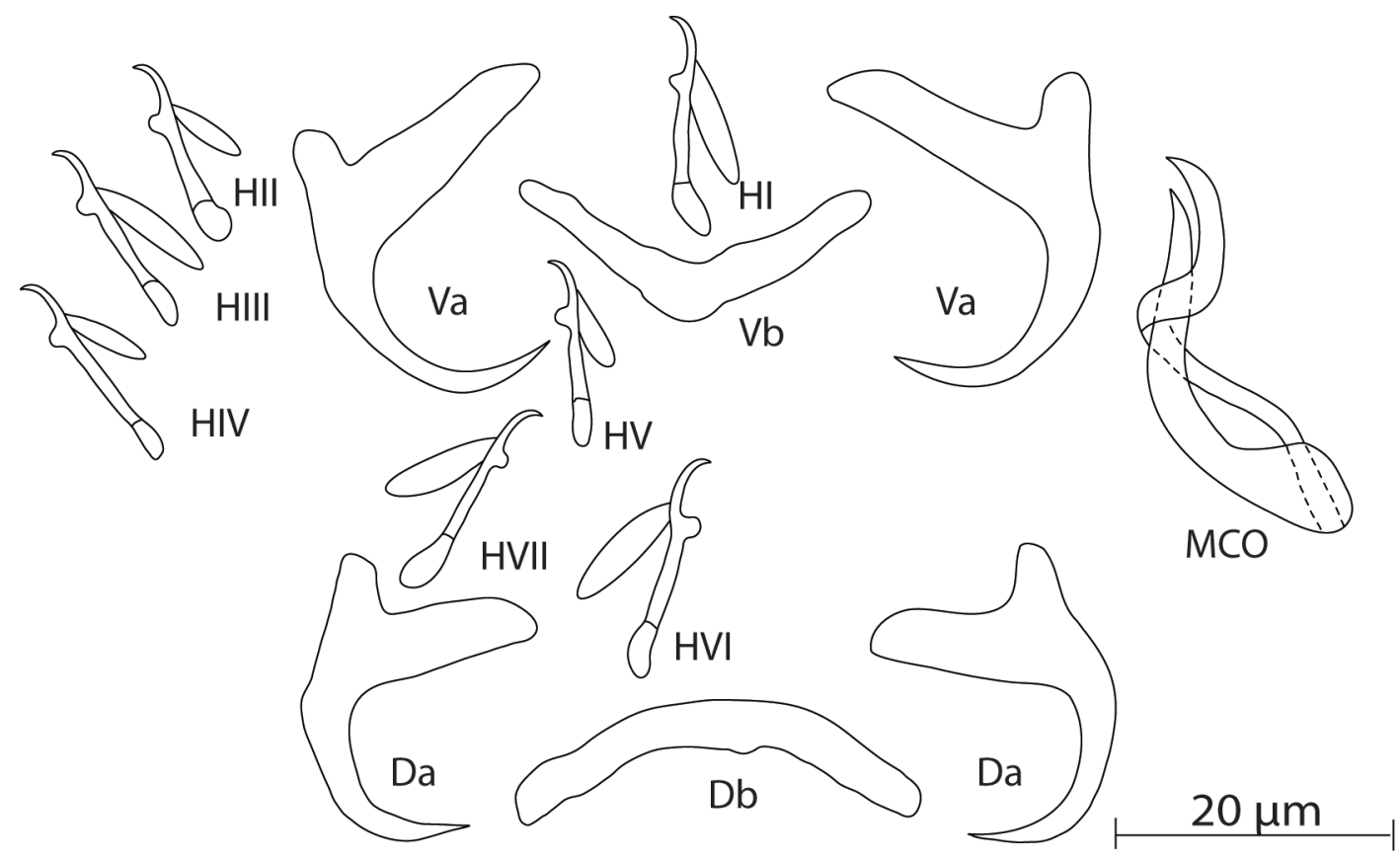

Figure 7. Sclerotized structures of Kapentagyrus limnotrissae collected from Limnothrissa miodon. Va-ventral anchors. Da-dorsal anchors. Db-dorsal bar. Vb-ventral bar. H-hooks (pairs I to V - ventral; pairs VI, VII-dorsal). MCO-male copulatory organ (ventral view)

lato include the genera Haplocleidus Mueller, 1936, Urocleidus Mueller, 1936 and Actinocleidus Mueller, 1934 but these all differ from Kapentagyrus in the shape of their haptoral bars and in the smaller-sized or near-undeveloped anchor roots. Kapentagyrus is morphologically similar to Cleidodiscus from North America but the latter genus differs in having nearundeveloped anchor roots and a relatively larger anchor shaft, compared to the anchors' base. Moreover, there are some marine dactylogyrid genera similar to Ancyrocephalus. Representatives of Ligophorus Euzet and Suriano, 1977 have well developed outer and inner anchor roots like Kapentagyrus but differ in the presence of auricles in the dorsal bar. Unlike Kapentagyrus, representatives of Haliotrema Johnston and Tiegs, 1922 and Euryhaliotrema Kritsky and Boeger, 2002 are characterised by an almost undeveloped outer root of the anchors compared to the inner one. A noticeable difference between Kapentagyrus and Lethrinitrema Lim and Justine, 2011 and Bravohollisia Bychowsky and Nagibina, 1970, respectively, is the wider base of the anchors' shaft in the latter two genera. Despite the observed similarities with other genera from different continents, the combination of (1) well-developed anchor roots together with (2) the presence of two V-shaped transversal haptoral bars without auricles is unique to the proposed monogenean genus Kapentagyrus. Based on the above-mentioned characteristics and its similarity to $K$. limnotrissae, Ancyrocephalus pellonulae described from the African freshwater clupeid Pellonula leonensis Boulenger, 1916 is here reassigned to Kapentagyrus as Kapentagyrus pellonulae.

Zoobank registration. To comply with the regulations set out in article 8.5 of the amended 2012 version of the International Code of Zoological Nomenclature (ICZN) (International Commission on Zoological Nomenclature, 2012), details of the species have been submitted to ZooBank. The Life Science Identifier (LSID) of the article is urn:1sid:zoobank .org:pub:536737D1-44FE-4CF798B9-458AEDD6DC4D. The LSID for the new genus Kapentagyrus is urn:1sid:zoobank .org:act:D4D37CABF21C-46BB-B4AC-6A2D1BD8EE86.

Family: Dactylogyridae Yamaguti, 1963

Genus: Kapentagyrus

Kapentagyrus limnotrissae (Paperna, 1973) comb. nov.

Ancyrocephalus limnotrissae Paperna, 1979: plate XXVIII, figs.1-7

Figures: 6a, b, 7

Type-host. Limnothrissa miodon (Boulenger, 1906) (Clupeidae) 
Type locality. Lake Tanganyika, Tanzania

Vouchers. MRAC MT. 38198-200,202 (6 specimens); MNHN HEL739-40 (4 specimens); NHMUK 2018.4.13.1 (4 specimens); SAMC-A089966 (6 specimens); MZH 10076-79 (4 specimens).

Additional localities. Bujumbura (323'S-29 $\left.22^{\circ} \mathrm{E}\right), \quad$ Kalemie $\quad\left(5^{\circ} 56^{\prime} \mathrm{S}-29^{\circ} 12^{\prime} \mathrm{E}\right)$, Kigoma Bay $\left(4^{\circ} 88^{\prime} \mathrm{S}-29^{\circ} 61^{\prime} \mathrm{E}\right), \quad$ Kirango

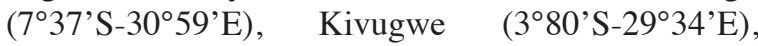
Lufubu Bay $\left(8^{\circ} 38^{\prime} \mathrm{S}-30^{\circ} 47^{\prime} \mathrm{E}\right)$, Moba Bay $\left(7^{\circ} 03^{\prime} \mathrm{S}-29^{\circ} 47^{\prime} \mathrm{E}\right), \quad$ Mpulungu $\quad\left(8^{\circ} 46^{\prime} \mathrm{S}-31^{\circ} 07^{\prime} \mathrm{E}\right)$, Mvugo $\quad\left(4^{\circ} 29^{\prime} \mathrm{S}-2^{\circ} 57^{\prime} \mathrm{E}\right), \quad$ Mvuna Island

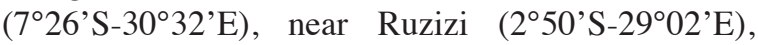
Rumonge ( $\left.3^{\circ} 97^{\prime} \mathrm{S}-29^{\circ} 43^{\prime} \mathrm{E}\right)$, Malagarasi River Delta (05 $14^{\prime}$ 'S-2947'E)

Site of infection. Gills.

Infection parameters. 49 of 144 fish infected with 1 - 15 specimens. Based on the population samples that included at least over 20 host individuals, the average prevalence of $K$. limnotrissae was $35 \%$ with a mean infection intensity of 1.7 .

Diagnosis. Kapentagyrus limnotrissae is the type species of the genus, infecting gills of L. miodon, characterized mainly by the proportion between the inner/outer root length of both ventral and dorsal anchors, which is around value 3 .

Description. [Based on 106 specimens; Figs. 6 a and b; 7, see measurements in Table 2]. Kapentagyrus limnotrissae is characterised by a pair of dorsal and ventral anchors with more developed inner roots compared to the outer ones and a regularly curved point. Dorsal and ventral bars are V-shaped with similar branch lengths and constant width. Hooks: 7 pairs, pairs 2, 3, 4, 6 and 7 same size and slightly longer compared to pair 1 and 5. MCO formed by slightly curved copulatory tube narrowed at distal extremity and accessory piece coiled once around the tube. Sclerotized vagina not observed.

Discussion: Specimens of $K$. limnotrissae were identified based on comparison with the holotype material. Importantly, as mentioned in the original description, it differs from Ancyrocephalus sensu stricto Creplin, 1839 by the developed roots of both the dorsal and the ventral anchor, the longer anchor shafts, the different shape of the haptoral transversal bars and the non-triangular shape of the accessory

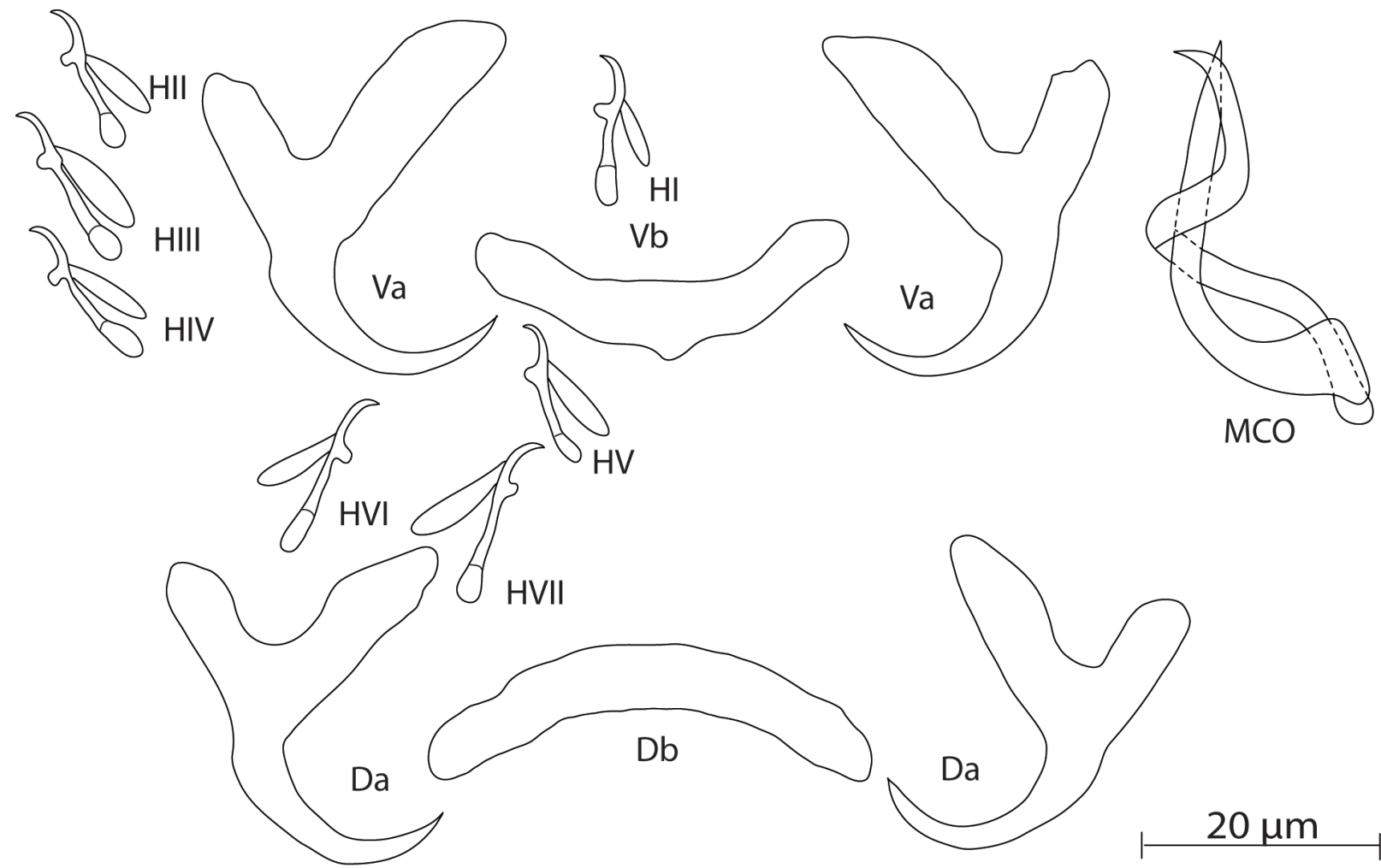

Figure 8. Sclerotized structures of Kapentagyrus tanganicanus collected from Limnothrissa miodon. Va-ventral anchors. Da-dorsal anchors. Db-dorsal bar. Vb-ventral bar. H-hooks (pairs I to V-ventral; pairs VI, VII-dorsal). MCO-male copulatory organ (ventral view) 


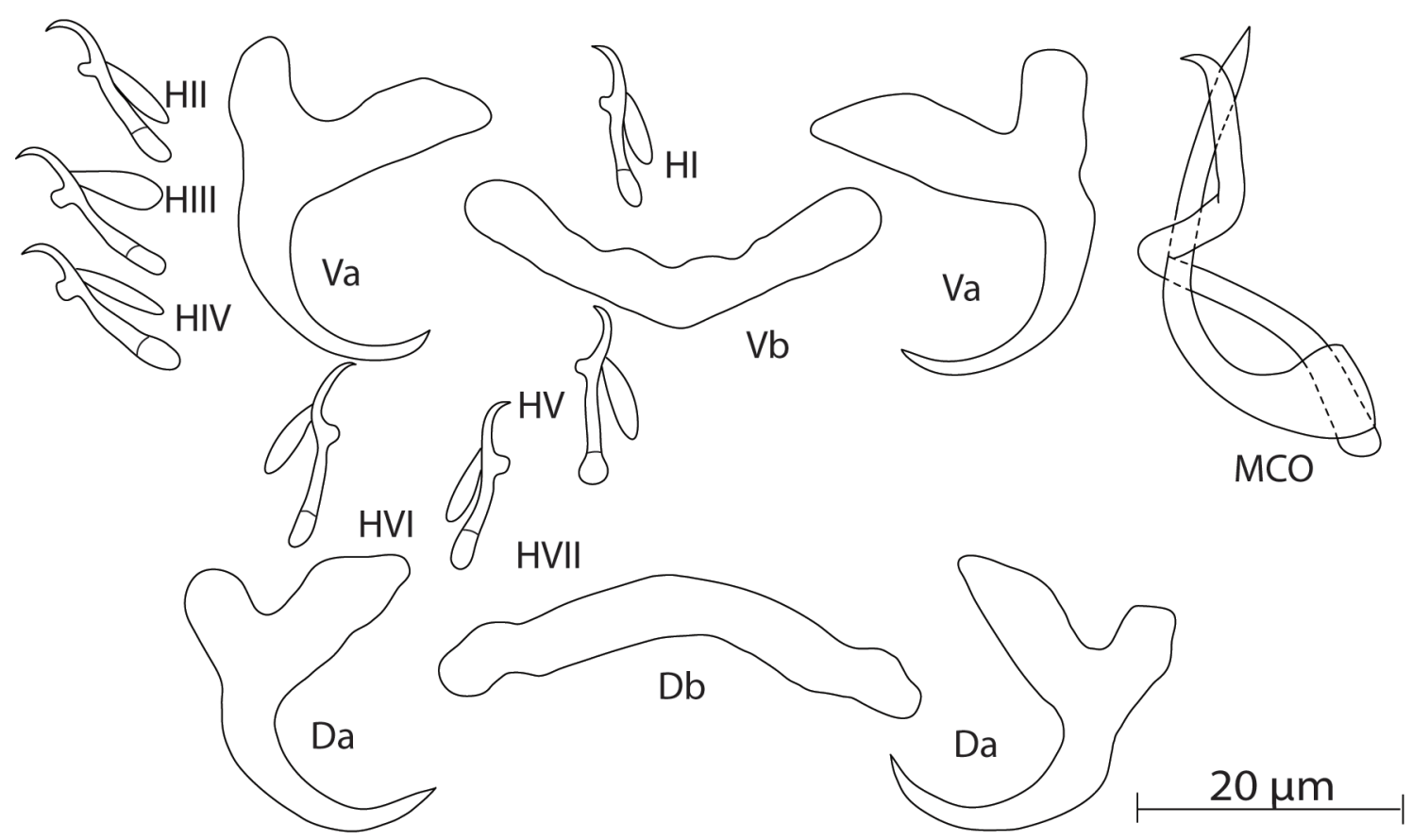

Figure 9. Sclerotized structures of Kapentagyrus tanganicanus collected from Stolothrissa tanganicae. Va-ventral anchors. Da-dorsal anchors. Db-dorsal bar. Vb-ventral bar. H-hooks (pairs I to V-ventral; pairs VI, VII-dorsal). MCO-male copulatory organ (ventral view)

piece of the MCO. Differential diagnosis with other congeners is provided in the description of $K$. tanganicanus.

Zoobank registration. To comply with the regulations set out in article 8.5 of the amended 2012 version of the International Code of Zoological Nomenclature (ICZN) (International Commission on Zoological Nomenclature, 2012), details of the species have been submitted to ZooBank. The Life Science Identifier (LSID) of the article is urn:1sid:zoobank .org:pub:536737D1-44FE-4CF798B9-458AEDD6DC4D. The LSID for the new name Kapentagyrus limnotrissae is urn:lsid:zoobank. org : a c t : 0 B 7 EFDF 3 - 9 B 45 - 42 B 5 - 94 A B B6ED07D397E5.

Family: Dactylogyridae Yamaguti, 1963

Genus: Kapentagyrus

Kapentagyrus tanganicanus Kmentová, Gelnar and Vanhove, sp. nov.

Figure: $6 \mathrm{c}-\mathrm{f}, 8,9$

Type host. Stolothrissa tanganicae Regan, 1917 (Clupeidae)

Additional host. Limnothrissa miodon (Boulenger, 1906) (Clupeidae)
Type locality. Uvira ( $\left.3^{\circ} 22^{\prime} \mathrm{S} 29^{\circ} 08^{\prime} \mathrm{E}\right)$

Type material. Holotype: MRAC MT. 38201; Paratypes: MRAC MT. 38203-205 (5 specimens); MNHN HEL741-43 (4 specimens); NHMUK 2018.4.13.2-13.3 (6 specimens); SAMC-A089967-70 (11 specimens); MZH 10072-75 (4 specimens).

Additional localities. S. tanganicae - Bujumbura ( $\left.3^{\circ} 23^{\prime} \mathrm{S}-29^{\circ} 22^{\prime} \mathrm{E}\right)$, Kalambo Lodge ( $\left.{ }^{\circ} 59^{\prime} \mathrm{S}-31^{\circ} 18^{\prime} \mathrm{E}\right)$, Kalemie $\quad\left(5^{\circ} 56^{\prime} \mathrm{S}-29^{\circ} 12^{\prime} \mathrm{E}\right)$, Kigoma Bay

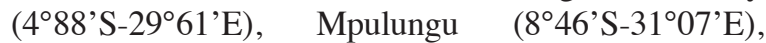

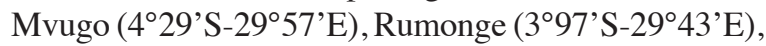
Uvira ( $\left.3^{\circ} 22^{\prime} \mathrm{S} 29^{\circ} 08^{\prime} \mathrm{E}\right)$, Utinta Bay (7 $\left.7^{\circ} 11^{\prime} \mathrm{S}-30^{\circ} 52^{\prime} \mathrm{E}\right)$; L. miodon - Kasasa Bay ( $\left.8^{\circ} 31^{\prime} \mathrm{S}-30^{\circ} 42^{\prime} \mathrm{E}\right)$, Kirango

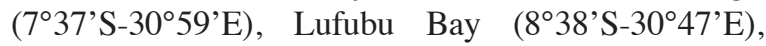

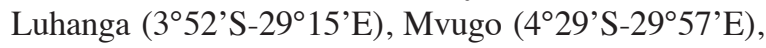
Mvuna Island $\quad\left(7^{\circ} 26^{\prime} \mathrm{S}-30^{\circ} 32^{\prime} \mathrm{E}\right)$, Rumonge (397'S-2943'E)

Infection parameters: 46 of 241 specimens of S. tanganicae infected with $1-7$ specimens. 27 of 144 specimens of $L$. miodon infected with $1-37$ specimens. The average prevalence was $40 \%$ in $L$. miodon with a mean infection intensity of 3.5 and $18 \%$ in S. tanganicae with mean infection intensity 1.5 . While higher prevalence values of $K$. tanganicanus were observed in S.tanganicae in the northern (21.5\%) compared to the central $(0 \%)$ and southern part of the 
lake $(4.2 \%)$, the mean infection intensity remained the same (4.5) in the northern and southern sub-basins.

Etymology. The species epithet is based on both the species epithet of the type host Stolothrissa tanganicae and the name of the ecosystem, Lake Tanganyika.

Diagnosis. Kapentagyrus tanganicanus is a monogenean species infecting gills of L. miodon and $S$. tanganicae in Lake Tanganyika, mainly characterized by the proportion between the inner/outer root length of both ventral and dorsal anchors, which is around value 2 .

Description. [Based on 139 specimens; Figs. 6c-f; 8,9 , see measurements in Table 2.]. Dorsal and ventral anchors with different outer and inner root sizes and regularly curved points. Ventral anchors larger in total size with on average longer inner root compared to dorsal anchors. Hooks 7 pairs, pairs 2, 3, 4, 6 and 7 of same size and slightly longer compared to pairs 1 and 5. Dorsal and ventral bar wide, long, V-shaped with constant width. Dorsal bar with longer branches compared to ventral bar. Male copulatory organ formed by slightly curved copulatory tube and accessory piece coiled once around the tube. Sclerotized vagina not observed. Based on morphometric results showing a consistent pattern, phenotypic variation in $K$. tanganicanus from L. miodon and S. tanganicae, respectively, was observed (see Table 3 ).

Discussion. The most similarcongenerhitherto known is $K$. limnotrissae. These two species differ mainly by the more asymmetrical anchor roots in K. limnotrissae: the proportion inner/outer root length of both ventral and dorsal anchors is around 3, whereas this proportion is close to 2 in $K$.tanganicanus. Given that the size of the hooks is almost identical, the relative size of the anchors compared to the marginal hooks is greater in $K$. tanganicanus. Another monogenean species described from a freshwater clupeid host in Africa which was reassigned to Kapentagyrus is K. pellonulae infecting Pellonula leonensis in Lake Volta. Based on the original description by Paperna, 1969 and the holotype (MRAC MT. 35572) we see a high similarity to both species from Lake Tanganyika with differences mainly in the size of the MCO (the average size of the copulatory tube in K. limnotrissae and K. tanganicanus is $30.4 \pm 2.5 \mu \mathrm{m}$ and $39.5 \pm 4.3 \mu \mathrm{m}$, respectively, compared to $25 \mu \mathrm{m}$ in the original description of $K$. pellonulae) and the more similar length of inner and outer dorsal anchor roots in the case of $K$. pellonulae.

Zoobank registration. To comply with the regulations set out in article 8.5 of the amended 2012 version of the International Code of Zoological Nomenclature (ICZN) (International Commission on Zoological Nomenclature, 2012), details of the new species have been submitted to ZooBank. The Life Science Identifier (LSID) of the article is urn:lsid:zoobank.org:pub:536737D144FE-4CF7-98B9-458AEDD6DC4D. The LSID for the new name Kapentagyrus tanganicanus is urn:1sid:zoobank.org:act:1B59CB96-864B-45198F75-CF5F36782247. 